\title{
Vertical distribution of micro- and nanoplankton in the San Francisco Estuary in relation to hydrography and predators
}

\author{
Gretchen C. Rollwagen-Bollens ${ }^{1, *}$, Stephen M. Bollens ${ }^{1}$, Deborah L. Penry ${ }^{2}$ \\ ${ }^{1}$ School of Biological Sciences, Washington State University Vancouver, 14204 NE Salmon Creek Avenue, Vancouver, \\ Washington 98686, USA \\ ${ }^{2}$ Department of Integrative Biology, University of California at Berkeley, Berkeley, California 94720, USA
}

\begin{abstract}
Temperate estuaries are characterized by significant seasonal variability in the vertical salinity gradient, which, along with biological factors, may play a role in determining plankton vertical distribution. We examined the vertical distribution of microplankton (20 to $200 \mu \mathrm{m})$ and nanoplankton $(\sim 5$ to $20 \mu \mathrm{m})$ in the San Francisco Estuary (SFE) over diel, seasonal and interannual time scales, and assessed the degree to which abiotic (hydrography) and biotic (predation) factors influenced these patterns. We sampled 2 hydrographically-distinct locations within the SFE: San Pablo Bay, a partially-mixed estuary, and South Bay, a lagoonal estuary. We conducted replicate Niskin bottle casts during the day and night at each location on 6 occasions between 1998 and 1999. We also conducted replicate day and night pump sampling for mesozooplankton (>153 $\mu \mathrm{m})$ on 4 of these dates. The vertical distribution of micro- and nanoplankton was often homogeneous with depth, even under substantially different hydrographic conditions. ANOVA testing of weighted mean depths (WMD) of chlorophyll, major taxa of micro- and nanoplankton, and copepods (factors: location, year, season, time of day) revealed that only the microplankton taxa (specifically ciliates) showed significant differences in vertical distribution over the sampling period. The most significant differences in WMD were observed seasonally. Ciliates and copepods (Acartia spp.) showed significant diel differences in WMD on several occasions, but diel differences were rarely observed among other micro- and nanoplankton. The degree of salinity stratification was never correlated to WMD of any micro- or nanoplankton group, however vertical distributions of heterotrophic loricate and aloricate ciliates and dinoflagellates were often significantly correlated with distributions of chlorophyll and autotrophic nanoflagellates (presumed food), as well as with the vertical distributions of Acartia spp (presumed predators). We conclude that micro- and nanoplankton are often relatively homogeneously distributed with respect to depth in the SFE. However, when micro- and nanoplankton distributions were more heterogeneous, biotic factors had a greater influence on vertical distribution than abiotic factors (stratification) in the SFE.
\end{abstract}

KEY WORDS: Vertical distribution - Microzooplankton · Ciliates · Flagellate - Nanoplankton · Copepods $\cdot$ Estuaries $\cdot$ San Francisco Bay $\cdot$ Stratification

\section{INTRODUCTION}

Estuaries are highly dynamic aquatic systems in both the horizontal and vertical dimensions, where salinity and current speed may vary substantially on an hourly, daily, annual and interannual basis. Moreover, temperate estuaries experience a wide range of precipitation and riverine inputs, leading to significant seasonal variability in the vertical salinity gradient. A key question for estuarine ecology is therefore the degree to which variability in the physical environment, in addition to biological factors, may affect the vertical distribution of planktonic organisms.

Changes in plankton vertical distribution in response to environmental stimuli have primarily been examined among meso- and macrozooplankton (or- 
ganisms $>200 \mu \mathrm{m}$ in size), in particular copepods. Diel vertical migration behavior has been observed in many copepod taxa, as a response to light (e.g. Stearns \& Forward 1984), to avoid visual predators (e.g. Bollens \& Frost 1989), to exploit food resources (e.g. Uchima \& Hirano 1988), or to maintain position within a large estuary (e.g. Laprise \& Dodson 1994). However, much less is known about the factors influencing the vertical distribution of microplankton (20 to $200 \mu \mathrm{m}$ ) or nanoplankton (2 to $20 \mu \mathrm{m})$, especially in estuaries.

Ciliated protozoans dominate estuarine microplankton (Porter et al. 1985, Revelante \& Gilmartin 1990, Pierce \& Turner 1992, G. C. Rollwagen-Bollens \& D. L. Penry unpubl.). Recent studies have demonstrated that some marine ciliate species are capable of limited vertical migration (Dale 1987, Jonsson 1989, Perez et al. 2000). For example, the swimming speed of the mixotrophic aloricate ciliate Myrionecta rubra (= Mesodinium rubrum) is as high as $8.5 \mathrm{~mm} \mathrm{~s}^{-1}$ (Lindholm 1985, Jonsson \& Tiselius 1990), and this species also migrates vertically (Smith et al. 1979, Dale 1987, Figueroa et al. 1998). Motile flagellates are abundant nanoplankton taxa in estuaries (Porter et al. 1985, Dolan \& Coats 1990, G. C. Rollwagen Bollens \& D. L. Penry unpubl.). Thus, in addition to passive shifts in vertical distribution due to mixing or other physical conditions, many estuarine micro- and nanoplankton taxa may have the ability to actively change their position in the water column in response to abiotic and biotic factors.

The San Francisco Estuary (SFE) is one of the largest temperate estuaries in North America and an important habitat for a wide range of fish and invertebrate species. The SFE is also shallow (mean depth $6 \mathrm{~m}$ ), such that benthic suspension feeders may consume a substantial proportion of planktonic production (Cloern 1982, Jassby et al. 2002). Water column hydrography (e.g. stratification) is therefore an important physical factor that affects both the abundance and vertical distribution of plankton in the SFE. For example, during periods of strong density stratification, typically late winter and spring, plankton may be sequestered into the upper and lower water column. Those organisms in the upper layer have access to light and nutrients, and are isolated from benthic grazers, resulting at least initially in a vertical distribution skewed toward the surface (Cloern 1982, 1991, 1996). Biological factors such as predation may also affect the vertical distribution of micro- and nanoplankton in estuaries. In addition to benthic grazing, there is a robust community of zooplankton consumers in the SFE, most notably herbivorous and omnivorous copepods (Ambler et al. 1985, Kimmerer \& Orsi 1996, Bollens et al. 2002, Purkerson et al. 2003).

Understanding the factors that influence the vertical distribution of micro- and nanoplankton in estuaries, and in marine systems more generally, is especially important given the significant role that these organisms play in the pelagic food web. Numerous field studies have demonstrated that heterotrophic and/or mixotrophic ciliates, dinoflagellates and small flagellates $<200 \mu \mathrm{m}$ in size (i.e. 'microzooplankton') are the major grazers of phytoplankton carbon in marine systems (e.g. Landry et al. 1995, Tamigneaux et al. 1997, Lessard \& Murrell 1998, Suzuki et al. 2002, Landry \& Calbet 2004), as well as significant bacterivores (Sherr \& Sherr 1987, 1994, Vacqué et al. 1992, Strom 2000). Moreover, ciliates and flagellates may comprise a significant proportion of copepod diets in both marine and estuarine environments (Gifford \& Dagg 1991, Kleppel 1992, Buskey et al. 1993, Fessenden \& Cowles 1994, Kleppel et al. 1996, Verity \& Paffenhöfer 1996, Nejstgaard et al. 1997, Zeldis et al. 2002, Rollwagen-Bollens \& Penry 2003). Thus, microzooplankton often serve to connect microbial production to the larger metazoan food web.

Despite their importance in pelagic food webs, studies of their distribution in estuarine systems has been relatively limited, particularly in the SFE. For example, a number of long term studies in the SFE have examined fish populations (e.g. Stevens 1977, Armor \& Herrgesell 1985, Meng et al. 1994, Gewant \& Bollens 2005), benthic invertebrates (e.g. Nichols 1985, Alpine \& Cloern 1992), macro- and mesozooplankton (e.g. Ambler et al. 1985, Kimmerer \& Orsi 1996, Bollens et al. 2002, Hooff \& Bollens 2004, Gewant \& Bollens 2005), water quality (e.g. Smith et al. 1979, Thompson et al. 2000), and particularly the rates of and limits on primary productivity (e.g. Cloern et al. 1985, Cloern 1987, Jassby et al. 2002). Prior to the present study and related projects, there had been no effort to measure the contribution of heterotrophic protist plankton $<200 \mu \mathrm{m}$ (microzooplankton) to overall planktonic abundance and food web dynamics.

In order to address this gap, in 1997 we established a $3 \mathrm{yr}$ field and experimental program to assess the abundance, distribution and composition of microzooplankton in the saline reaches of the SFE, with the major goal of characterizing the potential role of microzooplankton as trophic links between metazoans (i.e. copepods) and the microbial food web.

Our research program consisted of 3 elements. First, in order to assess the availability of potential protist prey for mesozooplankton, we measured the temporal and geographic variability in abundance, biomass and composition of microplankton $(20$ to $200 \mu \mathrm{m})$ and nanoplankton ( $\sim 5$ to $20 \mu \mathrm{m})$ in the lower estuary from 1997 to 1999. This allowed seasonal comparisons as well as comparisons between the strong 1997 to 1998 El Niño and the 1999 La Niña event that followed. We found that the microplankton community was always 
dominated by heterotrophic/mixotrophic ciliate biomass (primarily the genera Strombidium, Tintinnopsis, Strobilidium, Codonellopsis), except during a brief, but extreme spring diatom bloom during the 1998 El Niño. In contrast, heterotrophic nanoplankton biomass (almost exclusively non-pigmented flagellates) was consistently much lower than the biomass of autotrophic cells (small diatoms and pigmented flagellates) (G. C. Rollwagen-Bollens \& D. L. Penry unpubl.).

Another important element of our overall research program was to experimentally assess the role of microzooplankton in the diet of Acartia spp. copepods, the dominant mesozooplankton consumers in the lower SFE. During incubations with Acartia spp. feeding upon the natural planktonic assemblage from the SFE in spring 2000, we observed that ciliates and large (15 to $20 \mu \mathrm{m}$ ) heterotrophic nanoflagellates were often preferentially consumed compared to diatoms and other autotrophic prey (Rollwagen-Bollens \& Penry 2003). In a separate, later study Bollens \& Sanders (2004) also found loricate ciliates to be a major component of the diet of larval herring in the SFE.

In this paper we present the results of the third component of the SFE field study, which had the following objectives: (1) to describe the vertical distribution of microplankton and nanoplankton at 2 locations in the SFE, San Pablo Bay (a partially-mixed estuary) and South Bay (a lagoon-type estuary), over diel, seasonal, and interannual time scales, and (2) to seek possible explanations for the observed vertical distribution patterns in relation to environmental conditions, both abiotic (e.g. hydrography) and biotic (e.g. planktonic predators).

\section{MATERIALS AND METHODS}

Study site. The SFE is comprised of 2 hydrographically distinct sub-estuaries, South Bay and San Pablo Bay, which connect via the Central Bay and discharge through the Golden Gate to the Pacific Ocean (see Fig. 1). Both bays are wide and shallow (mean depth = $6 \mathrm{~m})$ and are incised by a narrow, relatively deep ( 12 to $15 \mathrm{~m}$ ) channel (Conomos et al. 1985).

San Pablo Bay is the seaward embayment of the greater North Bay/Delta system, through which the Sacramento and San Joaquin rivers drain approximately $40 \%$ of the land area of California. The San Francisco Bay area is characterized by a Mediterranean climate, with 2 seasons defined primarily by the degree of precipitation: a cool, wet winter season (November through April) and a warm, occasionally foggy dry season (May through October). As a result, during winter and spring San Pablo Bay is a partiallymixed estuary, with high levels of freshwater inflow, along with short water residence times and high tur- bidity. In contrast, South Bay is a lagoon-type estuary with lower inputs of freshwater. The water column is relatively homogeneous with respect to temperature and salinity during much of the year, water residence time is on the order of months and turbidity is relatively low (Cloern et al. 1985, Conomos et al. 1985).

In both bays, blooms of phytoplankton occur during the wet season, however the timing and mechanisms for these blooms differ between the 2 locations. In South Bay an intense, but short-lived phytoplankton bloom occurs each spring, when pulses of freshwater, reduced winds and neap tides combine to produce strong density stratification. Phytoplankton in the surface layer are isolated from benthic grazers, allowing an increase in biomass (Cloern 1982, 1987, 1991).

Prior to 1986, late spring/early summer phytoplankton blooms also occurred in San Pablo Bay as decreasing river flow into the Bay allowed algal doubling time to exceed water residence time. Phytoplankton biomass decreased again in late summer due to light limitation, as turbidity increased during high winds and strong tidal currents (Cloern et al. 1985). However, in 1986 the Asian clam Potamocorbula amurensis was introduced into the SFE, and through its high filtering rate and wide salinity tolerance quickly eliminated any phytoplankton blooms in the northern reaches of the estuary (Nichols et al. 1990). Hence, chlorophyll a levels in San Pablo Bay were consistently low through the 1990s (Lehman 2000). However, since 1998, elevated phytoplankton biomass ( $>5$ to $10 \mu \mathrm{g}$ chlorophyll $a^{-1}$ ) in the San Pablo Bay channel has been observed nearly every spring (Rollwagen Bollens \& Penry 2003, US Geological Survey Menlo Park Water Quality website http://sfbay.wr.usgs.gov/access/wqdata/).

Field sampling. Micro- and nanoplankton: We sampled at 2 stations, 1 each in South Bay and San Pablo Bay (Fig. 1), using the 35-foot (11 m) RV 'Questuary'. Both stations were located in the relatively deep (water depth $\sim 12 \mathrm{~m}$ ) channel that bisects the entire SFE. Duplicate casts, using 2.51 Niskin bottles equipped with external Teflon springs at 5 depths $(2,4,6,8$, $10 \mathrm{~m})$, were conducted day and night at each station 3 times per year between February 1998 and August 1999, for a total of 6 day/night collections per station (Table 1). These collections spanned $2 \mathrm{yr}$, with 2 sets of samples obtained during each of 3 seasons: (1) wet season, pre-phytoplankton bloom (December to February); (2) wet season, during phytoplankton bloom (March to May); and (3) dry season (June to November). These time periods reflect the seasonality of phytoplankton biomass in the SFE, which has been extensively monitored and documented for $>30 \mathrm{yr}$ by the Water Quality group at the US Geological Survey Menlo Park, CA (http://sfbay.wr.usgs.gov/access/ wqdata/). 


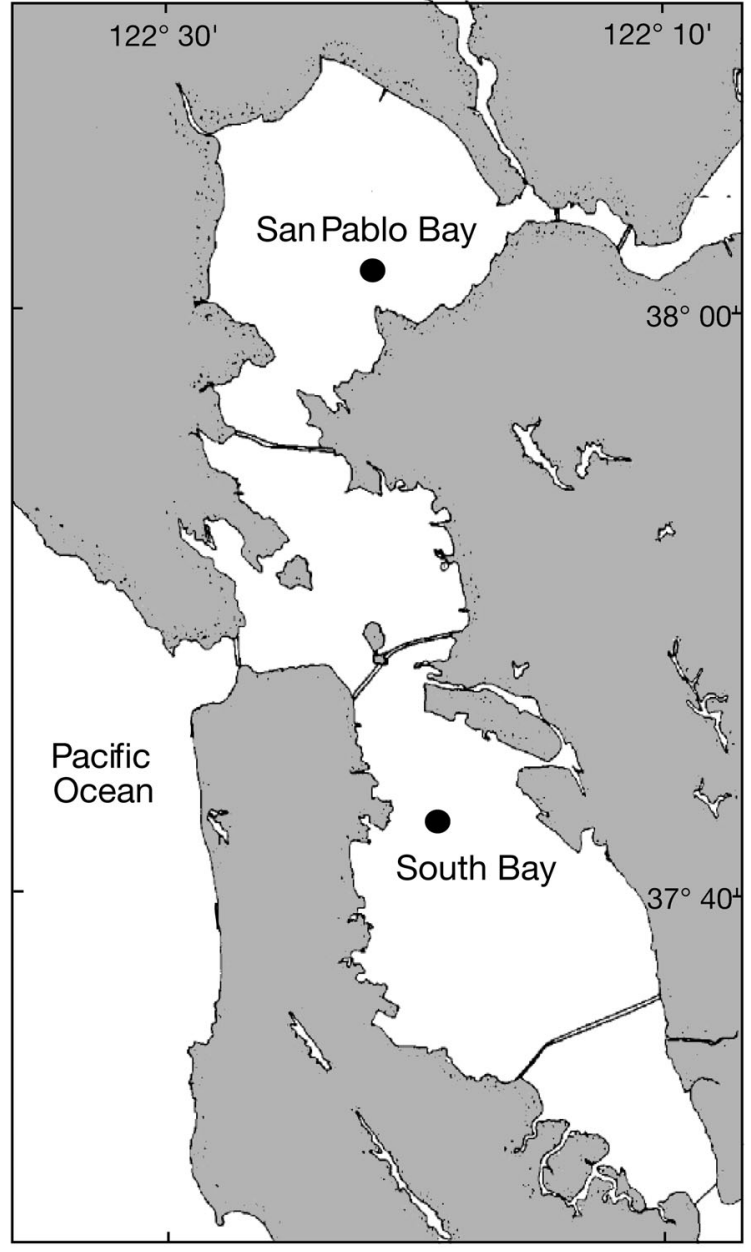

Fig 1. San Francisco Estuary. (๑) Locations where samples were collected in 1998 and 1999

Subsamples to measure chlorophyll a concentration, and to characterize the microplankton (20 to $200 \mu \mathrm{m})$ and nanoplankton $(\sim 5$ to $20 \mu \mathrm{m})$ components of the assemblage, were collected from each Niskin bottle. Subsamples (100 to $250 \mathrm{ml}$ ) for chlorophyll analysis were immediately filtered onto Whatman GF/F filters. The filters were wrapped in foil, frozen, and returned to the laboratory for fluorometric analysis (Strickland \& Parsons 1972) within 2 to $4 \mathrm{~d}$.

Subsamples for microplankton analysis were siphoned from the Niskin bottles into amber Nalgene bottles pre-filled with acid Lugol's solution (Throndsen 1978) to a final concentration of $10 \%$ (Gifford 1993). Subsamples for nanoplankton analysis were similarly siphoned into opaque Nalgene bottles pre-filled with cold gluteraldehyde, to a final concentration of $1 \%$. All sample bottles were kept chilled and returned to the laboratory within $24 \mathrm{~h}$ of collection. Lugol's preserved microplankton samples were then stored in the dark at $10^{\circ} \mathrm{C}$ until analyzed. Duplicate $20 \mathrm{ml}$ aliquots of the gluteraldehyde-preserved nanoplankton samples were stained with fluorescein isothiocyanate (FITC), filtered onto $1.0 \mu \mathrm{m}$ black polycarbonate filters, and mounted on glass slides (Sherr et al. 1993). The slides were kept frozen at $<0^{\circ} \mathrm{C}$ until analyzed.

Mesozooplankton: Mesozooplankton (>153 $\mu \mathrm{m})$ were collected concurrently with micro- and nanoplankton during April and August 1998, and March and August 1999. Discrete mesozooplankton samples from 5 depths $(2,4,6,8,10 \mathrm{~m})$ were obtained from water pumped through a $4 "(10 \mathrm{~cm})$ diameter hose into a $153 \mu \mathrm{m}$ plankton net submerged in a $190 \mathrm{l}$ container on deck. However, in August 1998 a $130 \mu \mathrm{m}$ plankton net was used for pump sampling in San Pablo Bay. Mesozooplankton are traditionally defined as organisms $>200 \mu \mathrm{m}$ in size (Sieburth et al. 1978), however the nets available to use for this study were 130 to $153 \mu \mathrm{m}$. This should not have affected our results since we excluded nauplii and specifically sorted the net samples only for copepodid and adult life stages, which for the most abundant mesozooplankton taxa in the SFE were $>200 \mu \mathrm{m}$ in size. After 5 min pumping at each depth, the mesozooplankton were rinsed into the net's collecting bucket, transferred to sample bottles, and preserved in $4 \%$ buffered formalin. Pump rates $\left(1 \mathrm{~min}^{-1}\right)$ were measured at the beginning and end of each cast and averaged, in order to calculate the volume of water filtered for each sample from that cast. The volume of water pumped during each cast averaged $0.86 \pm$ 0.021 (data not shown).

Hydrography: Temperature and salinity profiles from the surface to near bottom $(\sim 10$ to $11 \mathrm{~m})$ were obtained at the beginning of each Niskin bottle/pump cast using a Seabird SBE19 CTD. The data were binned into $0.25 \mathrm{~m}$ depth bins using SEASOFT software, and then averaged between the 2 replicate casts to produce mean day and night profiles of temperature and salinity for each sampling period. Tidal stage (e.g. flood, slack, ebb) was also noted at the beginning of each cast.

Organism enumeration and identification. Microplankton: Aliquots of 25 to $50 \mathrm{ml}$ from each Lugol sample bottle were settled overnight in Utermöhl chambers, and the entire contents of the chamber between 20 and $200 \mu \mathrm{m}$ were enumerated using an inverted microscope at $200 \times$ magnification. In all samples, a minimum of 100 cells was counted, identified to genus where possible, and grouped into one of the following major prey categories: loricate ciliates, Myrionecta rubra (= Mesodinium rubrum) ciliates, aloricate nonMyrionecta ciliates, diatoms, or dinoflagellates.

It is difficult, and often impossible, to distinguish strictly heterotrophic aloricate ciliates and dinoflagellates from mixotrophic forms in Lugol-preserved sam- 
Table 1. Dates, starting times and tidal stage of sampling in South Bay and San Pablo Bay, San Francisco Estuary, between February 1998 and August 1999

\begin{tabular}{|c|c|c|c|c|c|c|}
\hline \multirow{2}{*}{ Season } & \multicolumn{3}{|c|}{ - San Pablo Bay } & \multicolumn{2}{|r|}{ - South Bay } & \multirow[b]{2}{*}{ Tidal stage } \\
\hline & Date & Time (h) & Tidal stage & Date & Time (h) & \\
\hline \multicolumn{7}{|l|}{1998} \\
\hline \multirow[t]{4}{*}{ Wet, non-bloom } & \multirow[t]{4}{*}{ Feb 20} & Day $1,14: 30$ & Late ebb/slack & \multirow[t]{4}{*}{ Mar 2} & Day 1, 15:15 & Slack/early ebb \\
\hline & & Day 2, 16:00 & Slack/early flood & & Day 2, no cast & \\
\hline & & Night $1,19: 50$ & Late flood & & Night 1, 19:45 & Late ebb \\
\hline & & Night $2,21: 40$ & Slack & & Night 2, 21:00 & Slack \\
\hline \multirow[t]{4}{*}{ Wet, bloom } & \multirow[t]{4}{*}{ Apr 13} & Day 1, 15:45 & Slack & \multirow[t]{4}{*}{ Apr 16} & Day $1,15: 45$ & Late flood/slack \\
\hline & & Day $2,16: 55$ & Early ebb & & Day 2, 17:05 & Slack/early ebb \\
\hline & & Night 1, 21:20 & Slack & & Night $1,21: 30$ & Slack \\
\hline & & Night $2,22: 35$ & Mid flood & & Night 2, 22:45 & Early flood \\
\hline \multirow[t]{4}{*}{ Dry } & \multirow[t]{4}{*}{ Aug 10} & Day 1, 17:00 & Slack/early ebb & \multirow[t]{4}{*}{ Aug 13} & Day 1, 15:55 & Late flood \\
\hline & & Day $2,18: 25$ & Mid ebb & & Day 2, 17:15 & Slack \\
\hline & & Night $1,22: 15$ & Slack & & Night $1,21: 40$ & Mid ebb \\
\hline & & Night 2, 23:25 & Mid flood & & Night 2, 23:25 & Late ebb \\
\hline \multicolumn{7}{|l|}{1999} \\
\hline \multirow[t]{4}{*}{ Wet, bloom } & \multirow[t]{4}{*}{ Mar 31} & Day $1,13: 50$ & Slack/early ebb & \multirow[t]{4}{*}{ Mar 26} & Day 1, 13:30 & Late ebb/slack \\
\hline & & Day 2, 15:10 & Mid ebb & & Day 2, 15:00 & Slack/early flood \\
\hline & & Night 1, 21:00 & Mid flood & & Night 1, 21:00 & Late flood \\
\hline & & Night $2,22: 50$ & Mid/late flood & & Night $2,21: 50$ & Slack \\
\hline \multirow[t]{4}{*}{ Wet, non-bloom } & \multirow[t]{2}{*}{ May 6} & Night $1,21: 45$ & Mid ebb & \multirow[t]{4}{*}{ Apr 19} & Day 1, 14:45 & Late flood \\
\hline & & Night $2,23: 35$ & Late ebb & & Day $2,16: 20$ & Slack \\
\hline & \multirow[t]{2}{*}{ May 7} & Day 1, 13:15 & Late ebb/slack & & Night 1, 21:00 & Slack \\
\hline & & Day $2,14: 45$ & Early flood & & Night 2, 22:50 & Early flood \\
\hline \multirow[t]{4}{*}{ Dry } & \multirow[t]{2}{*}{ Aug 16} & Night $1,21: 50$ & Mid ebb & \multirow[t]{4}{*}{ Aug 20} & Day 1, 13:15 & Late ebb/slack \\
\hline & & Night $2,23: 50$ & Late ebb & & Day 2, 14:40 & Slack/early flood \\
\hline & \multirow[t]{2}{*}{ Aug 17} & Day 1, 13:15 & Early flood & & Night $1,21: 20$ & Early ebb \\
\hline & & Day $2,14: 30$ & Mid flood & & Night $2,22: 50$ & Late ebb \\
\hline
\end{tabular}

ples. However, in our samples the mixotrophic ciliate Myrionecta rubra was typically readily identifiable. Moreover, there exists a growing body of research describing the unusual physiology and swimming behavior of M. rubra (e.g. Johnson \& Stoecker 2005). Therefore, $M$. rubra were grouped into their own category, while all other naked ciliates were lumped into the non-Myrionecta aloricate ciliate category and considered heterotrophic/mixotrophic. Based on studies of protozoan feeding in Chesapeake Bay (Dolan 1991) and other work reviewed in Nejstgaard et al. (2001), the ciliate taxa present in the SFE are most likely phagotrophic, ingesting bacterial, algal or flagellate prey, although some may also contain chloroplasts. In addition, large $(>20 \mu \mathrm{m})$ individuals of the dinoflagellate genera Protoperidinium and Gymnodinium (mostly G. breve) were categorized as heterotrophic since they are documented phagotrophs (Hansen 1991 and references therein).

Nanoplankton: A minimum of 100 cells between 5 and $20 \mu \mathrm{m}$ were counted from randomly selected fields using an epifluorescence microscope at 400 to $450 \times$ magnification. As the primary objective of these collections was to investigate protozoan-metazoan (copepod) trophic interactions (Rollwagen-Bollens \& Penry 2003, and unpubl.), only cells larger than $5 \mu \mathrm{m}$ were included. This is the threshold size for efficient capture and ingestion by Acartia spp. (Nival \& Nival 1976), which are among the dominant copepod consumers in this part of the SFE (Ambler et al. 1985, Bollens et al. 2002, Purkerson et al. 2003). Nanoplankton are traditionally defined as cells 2 to $20 \mu \mathrm{m}$ in size, and as such our analyses may have left out a potentially important component of small plankton between 2 and $5 \mu \mathrm{m}$ (e.g. Kuuppo 1994). There are no published data quantifying the abundance of heterotrophic nanoplankton $<5 \mu \mathrm{m}$ in the SFE. However, a long-term study of phytoplankton community composition in the SFE showed that this nutrient-rich estuary is dominated by large $(>30 \mu \mathrm{m})$ cells, with cells $<8 \mu \mathrm{m}$ contributing only $4 \%$ of community biomass (Cloern \& Dufford 2005). In addition, Cole et al. (1986) reported size fractioned chlorophyll a concentrations that showed the $<5 \mu \mathrm{m}$ fraction to account for $\sim 30$ to $40 \%$ of the chlorophyll $<20 \mu \mathrm{m}$ in both South Bay and San Pablo Bay. Cole et al. (1986) also observed that the chlorophyll biomass of phytoplankton cells $<5 \mu \mathrm{m}$ was low compared to that in other 
estuaries, such as the Hudson River estuary, Narragansett Bay and Chesapeake Bay. While this does not give information about the heterotrophic nanoplankton $<5 \mu \mathrm{m}$, it suggests that this component may also be low in the SFE relative to other estuaries. Cells were grouped into 2 major categories: autotrophic nanoplankton or heterotrophic nanoplankton (based on the presence or absence of chlorophyll autofluorescence within the cell).

Mesozooplankton: Preserved samples were subsampled with a Stempel pipette to a volume sufficient to allow enumeration of at least 300 organisms, and each individual was identified to the most specific taxonomic level and life history stage possible. In the case of the genus Acartia, the SFE is characterized by a group of subgenera and species, including Acartiura sp., Acartia tonsa, and A. californiensis. Individuals were identified as being a member of one of these species. However, for the purposes of this study, all were placed in the category Acartia spp.

Statistical analyses. In order to quantitatively describe the vertical distributions of chlorophyll $a$, micro- and nanoplankton, and mesozooplankton, we calculated a weighted mean depth (WMD) for each vertical profile using the following equation, modified from Bollens et al. (1993):

$$
\mathrm{WMD}=\frac{\sum\left(A_{i} \cdot Z_{i}\right)}{\sum\left(A_{i}\right)}
$$

where $i$ is each depth sampled, $A$ is abundance (cells $\mathrm{ml}^{-1}$ ) or chlorophyll a concentration $\left(\mu \mathrm{g} \mathrm{l}^{-1}\right)$, and $Z$ is the sampling depth (m). The WMDs from each replicate cast $(n=2)$ were then averaged to produce a mean $(+\mathrm{SE}) \mathrm{WMD}$ for each time period. More sophisticated techniques for comparing 2 vertical distributions, both with (Beet et al. 2003) and without (Solow et al. 2000) replication, have been recently described. However, the WMD approach allowed the calculation of a simple metric of vertical distribution that could then be analyzed across a number of different time and space scales using standard analysis of variance techniques.

We identified temporal and spatial patterns in the vertical distributions of micro- and nanoplankton by performing multiple ANOVAs using JMP Version 5.1.2 software for Macintosh on the WMD of all major taxonomic categories. The factors were year (levels: 1998, 1999), season (levels: wet season-non-bloom, wet season-bloom, dry season), time (levels: day, night) and location (levels: San Pablo Bay, South Bay). As an indication of diel vertical migration, differences in daytime vs. nighttime WMD of the major categories of microand nanoplankton during each sampling period were further tested using Student's $t$-tests, assuming unequal variance (Zar 1996).
Finally, to specifically compare the vertical distributions of micro- and nanoplankton with water column hydrography, as well as with potential predators, 2 approaches were used.

First, a stratification index $(\Delta \mathrm{S})$ was calculated for each cast as the difference between salinity at the surface and that at $10 \mathrm{~m}$. Salinity stratification has been shown to be a dominant factor affecting phytoplankton productivity in the SFE (e.g. Cloern et al. 1985, Jassby et al. 2002) and the primary distinguishing physical characteristic between San Pablo Bay and South Bay. Salinity stratification is also directly influenced by, e.g. tides, winds, and freshwater flow; thus, $\Delta \mathrm{S}$ serves as a convenient, easily measurable and statistically testable metric of hydrography in general. The $\Delta \mathrm{S}$ values were then compared with the WMD of all micro- and nanoplankton categories using Pearson's $r$ correlation statistic (Zar 1996) to assess the relationship of stratification and vertical distribution.

Second, we measured the potential effects of the most abundant mesozooplankton predators on microand nanoplankton vertical distribution, as well as the potential of microplankton predators to influence nanoplankton distribution, by using Pearson's r correlation statistic to compare the WMD of each potential predator population with each potential prey population.

\section{RESULTS}

The results of a 4-way ANOVA on stratification index and weighted mean depths of chlorophyll $a$, micro- and nanoplankton for all sampling times and locations indicated that the most significant differences in hydrography and plankton vertical distribution occurred on a seasonal and to some extent diel basis, with yearly and regional differences of lesser importance (Table 2). Moreover, the ANOVA results showed differences between the major categories of micro- and nanoplankton with respect to both time and location.

Therefore, in Figs. 2 to 5 we have presented the vertical distributions of each major micro- and nanoplankton taxonomic category by season and year in San Pablo Bay and South Bay, along with profiles of temperature and salinity to illustrate hydrography. These figures also include profiles of Acartia spp., to illustrate the distributions of the most abundant potential mesozooplankton predator at these sampling times and locations. Not shown in the figures, but included in the correlations analyses described below, are 2 additional copepod taxa (Limnoithona tetraspina and Oithona davisae) observed in these samples, but whose combined abundance was much lower and more variable than that of Acartia spp. 
Table 2. p-values from 4-way ANOVA tests for geographic and temporal variability in stratification index $(\Delta \mathrm{S})$, and weighted mean depths of microplankton $(20$ to $200 \mu \mathrm{m})$ and nanoplankton $(5$ to $20 \mu \mathrm{m})$ pooled for all sampling times and locations in San Francisco Estuary between February 1998 and August 1999. SPB: San Pablo Bay; SB: South Bay. Bold represents significant differences $\left({ }^{*} \mathrm{p}<0.05 ;{ }^{* *} \mathrm{p}<0.01 ;{ }^{* * *} \mathrm{p}<0.001\right)$. Spaces indicate insufficient data for analysis

\begin{tabular}{|c|c|c|c|c|}
\hline Parameter & $\begin{array}{l}\text { Geographic } \\
\text { (SPB vs. SB) }\end{array}$ & $\begin{array}{c}\text { Diel } \\
\text { (Day vs. Night) }\end{array}$ & $\begin{array}{c}\text { Seasonal } \\
\text { (Wet vs. dry) }\end{array}$ & $\begin{array}{c}\text { Interannual } \\
\text { (1998 vs. 1999) }\end{array}$ \\
\hline Stratification $(\Delta S)$ & $0.000^{* * *}$ & 0.234 & $0.000^{* * *}$ & 0.133 \\
\hline $\begin{array}{l}\text { Chlorophyll a } \\
\text { Microplankton }\end{array}$ & $0.003^{* *}$ & $0.001^{* * *}$ & 0.071 & $0.023^{*}$ \\
\hline Loricate ciliates & 0.355 & 0.215 & $0.001^{* * *}$ & 0.075 \\
\hline Aloricate ciliates & 0.314 & $0.000^{* * *}$ & $0.000^{* * *}$ & $\begin{array}{l}\mathbf{0 . 0 0 0} \\
0 . * *\end{array}$ \\
\hline $\begin{array}{l}\text { Diatoms } \\
\text { Dinoflagellates }\end{array}$ & 0.913 & 0.253 & $\begin{array}{l}\mathbf{0 . 0 0 4}^{* *} \\
0.567\end{array}$ & 0.222 \\
\hline \multicolumn{5}{|l|}{ Nanoplankton } \\
\hline $\begin{array}{l}\text { Nanodiatoms } \\
\text { Nanodinoflagellates }\end{array}$ & $0.003^{* *}$ & 0.795 & $\begin{array}{l}0.076 \\
0.648\end{array}$ & 0.211 \\
\hline $\begin{array}{l}\text { Autonanoflagellates } \\
\text { Heteronanoflagellates }\end{array}$ & es 0.670 & $0.010^{* *}$ & $\begin{array}{l}0.414 \\
0.497\end{array}$ & $0.036^{*}$ \\
\hline
\end{tabular}

\section{Temporal variability in hydrography and plankton vertical distribution}

Diel patterns

Hydrography. Statistically significant $(\mathrm{p}<0.05)$ differences between daytime and nighttime stratification indices $(\Delta S)$ were only occasionally observed. In San Pablo Bay, $\Delta \mathrm{S}$ differed between day and night only once, in August 1998 (Table 3). In South Bay, $\Delta \mathrm{S}$ differed between day and night in April/May and August of both years, although in all cases except April 1998 the magnitude of the diel difference was extremely small relative to the overall water column salinity (Table 3).

Plankton distribution. In San Pablo Bay diel differences were more evident in 1998 than in 1999 (Figs. 2 \& 3). During all three 1998 sampling periods, diatoms and/or Myrionecta rubra exhibited statistically significant differences in weighted mean depth during the day vs. night, although neither day nor night mean depth was consistently shallower or deeper than the other (Fig. 2). In South Bay, significant differences in plankton mean depths occurred only once, in March 1999, and then only among heterotrophic nanoplankton and Acartia spp. (Figs. 4 \& 5).
The exception to the overall lack of day-night differences in plankton vertical distribution was in August 1999 in both South Bay and San Pablo Bay. Myrionecta rubra, heterotrophic dinoflagellates and heterotrophic/mixotrophic aloricate ciliates were all distributed higher in the water column during the day in San Pablo Bay (Fig. 3). Similarly M. rubra and autotrophic nanoplankton mean depths were shallower during the day than at night in South Bay; however, Acartia spp. showed the opposite pattern, with a deeper mean depth during the day (Fig. 5).

\section{Seasonal patterns}

Hydrography. In both San Pablo Bay and South Bay, the stratification index was substantially higher (i.e. the water column was more stratified) during the winter/spring wet season than the summer dry seasons in both 1998 and 1999 (Table 3).

Plankton distributions. In San Pablo Bay, naked ciliates (both autotrophic Myrionecta rubra and other aloricate ciliate species) were concentrated deeper in the water column during the winter wet seasons than in the summer dry seasons (Figs. 2 \& 3, Table 4). However, in South Bay only the mean depths of diatoms and loricate ciliates showed a seasonal pattern, with both groups concentrated at deeper depths during the wet seasons than during the dry seasons (Figs. 4 \& 5, Table 4).

Table 3. Mean $( \pm \mathrm{SE})$ stratification indices $(\Delta \mathrm{S}$, in ppt), calculated as difference between salinity at surface and at $10 \mathrm{~m}$, for CTD casts in San Pablo Bay and South Bay in 1998 and 1999. Asterisks indicate statistically significant differences between day and night $\Delta \mathrm{S}$, using Student's $t$-test and assuming unequal variance $\left({ }^{*} \mathrm{p}<0.05 ;{ }^{* * *} \mathrm{p}<0.001\right)$. nd $=$ no data; $\mathrm{nr}=$ no replicate

\begin{tabular}{|c|c|c|c|c|}
\hline \multirow[t]{2}{*}{ Date } & \multicolumn{2}{|c|}{ San Pablo Bay } & \multicolumn{2}{|c|}{ South Bay } \\
\hline & Time & $\Delta \mathrm{S}$ & Time & $\Delta \mathrm{S}$ \\
\hline \multirow[t]{2}{*}{ Feb/Mar 1998} & Day & nd & Day & 4.33 (nr) \\
\hline & Night & $14.3(2.52)$ & Night & $1.75(0.02)$ \\
\hline \multirow[t]{2}{*}{ Apr 1998} & Day & $13.0(0 . .57)$ & Day & $4.97(0.30)$ \\
\hline & Night & $12.7(1.33)^{* * *}$ & Night & $3.38(0.50)^{*}$ \\
\hline \multirow[t]{2}{*}{ Aug 1998} & Day & $2.7(0.97)$ & Day & $0.08(0.10)$ \\
\hline & Night & $5.57(0.03)$ & Night & $0.44(0.14)^{*}$ \\
\hline \multirow[t]{2}{*}{ Mar 1999} & Day & $5.22(3.59)$ & Day & $0.28(0.23)$ \\
\hline & Night & $12.0(4.43)$ & Night & $11.18(0.69)$ \\
\hline \multirow[t]{2}{*}{ Apr/May 1999} & Day & $11.1(7.45)$ & Day & $0.43(0.11)$ \\
\hline & Night & $15.7(0.43)$ & Night & $0.06(0.08)^{*}$ \\
\hline \multirow[t]{2}{*}{ Aug 1999} & Day & $6.93(0.91)$ & Day & $0.15(0.08)$ \\
\hline & Night & $4.81(1.32)$ & Night & $0.29(0.02)^{*}$ \\
\hline
\end{tabular}


0
0
0
0
0
0
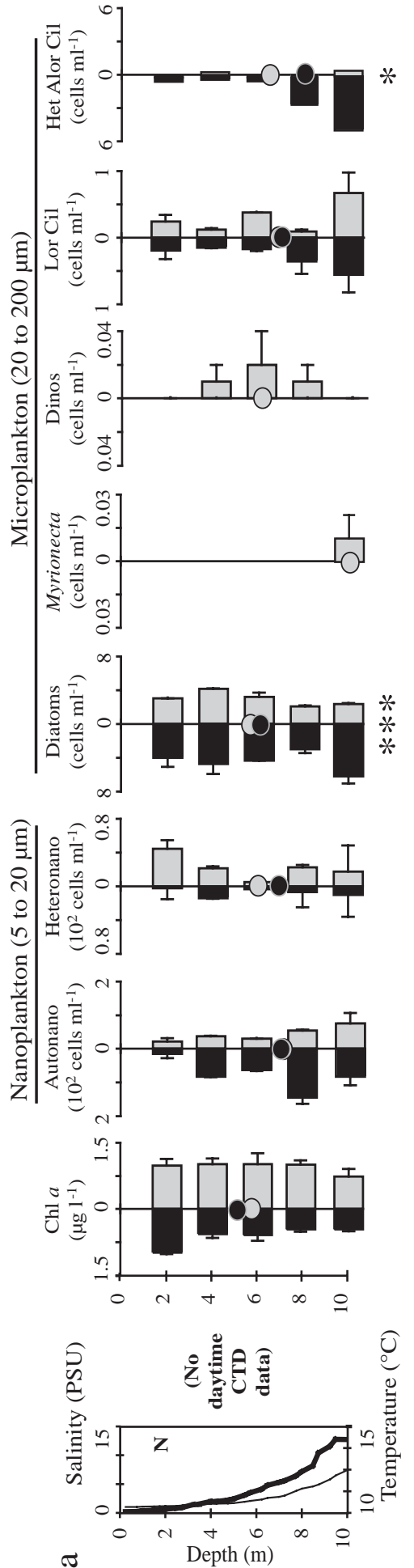

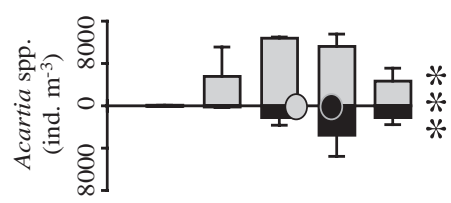

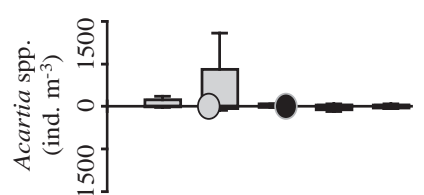

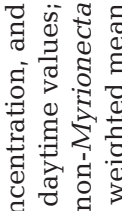

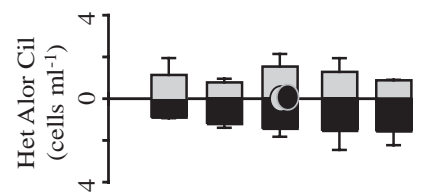

斯]

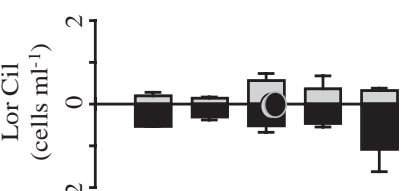

Intom
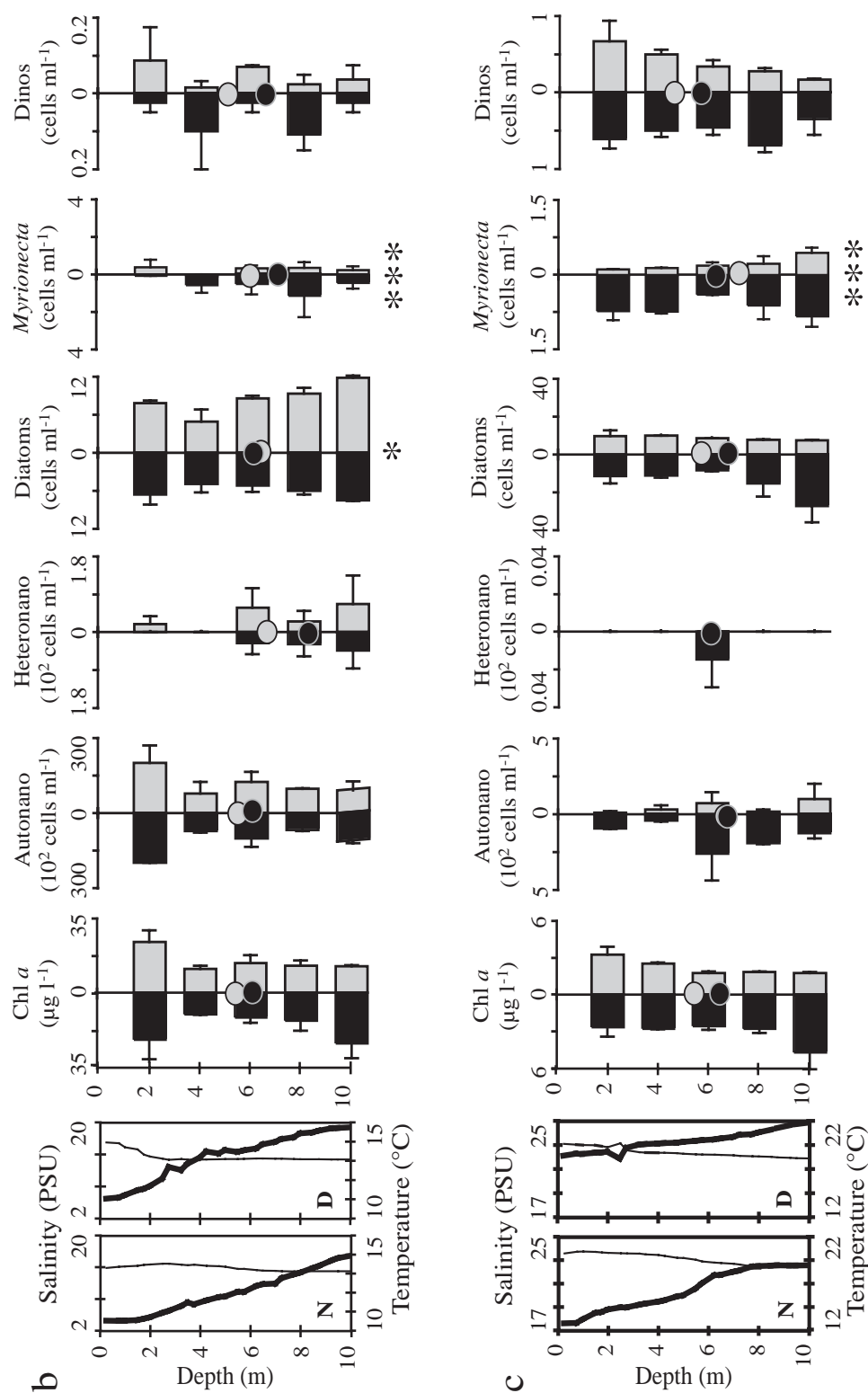

ชิ

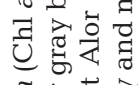

它式空

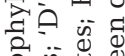

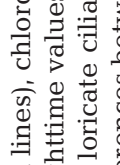

寻寈苑焉

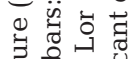

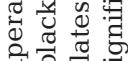

逭

动苋苛

$\exists$ is : $:$ :

불월

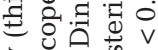

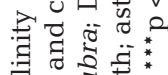

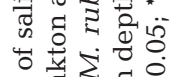

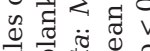

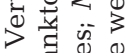

$\infty$ 눙

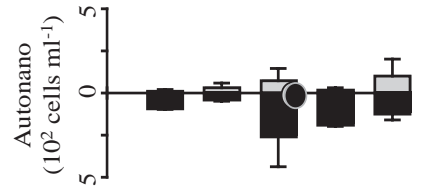

点诸元

형 눙

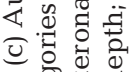

可

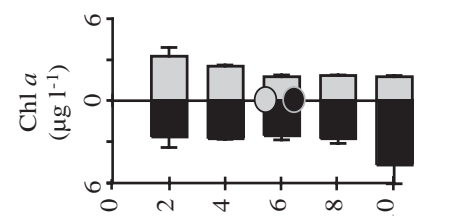

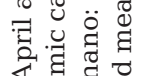

द्व

热证要

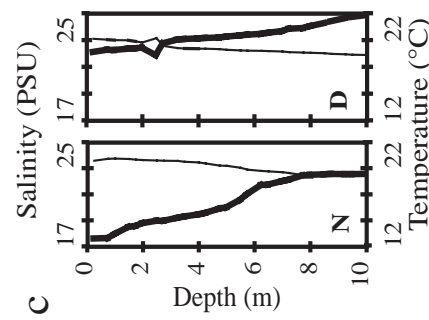

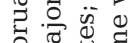

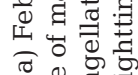

政

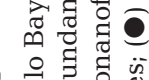

के

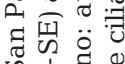

ง

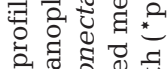

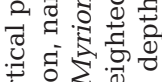

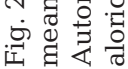



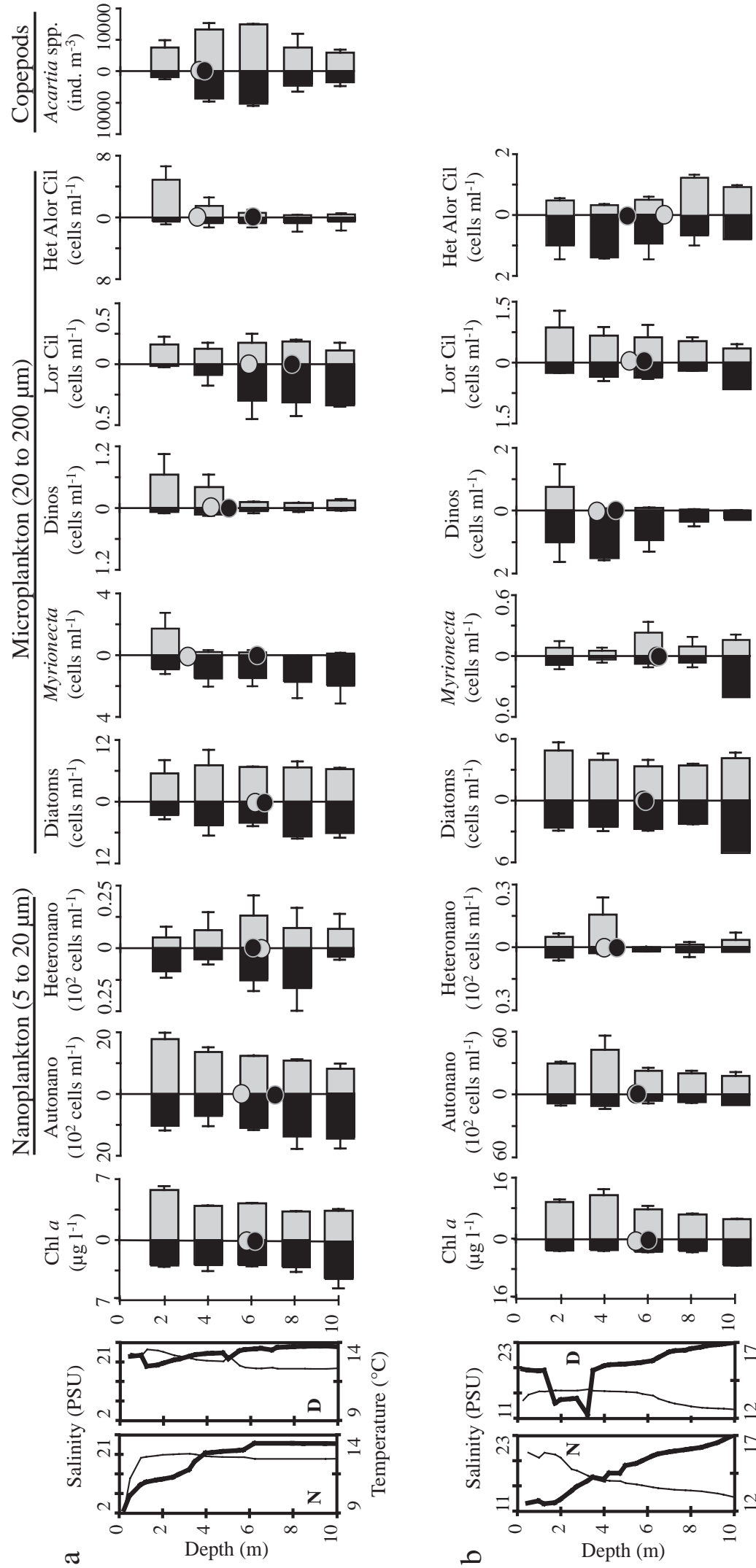
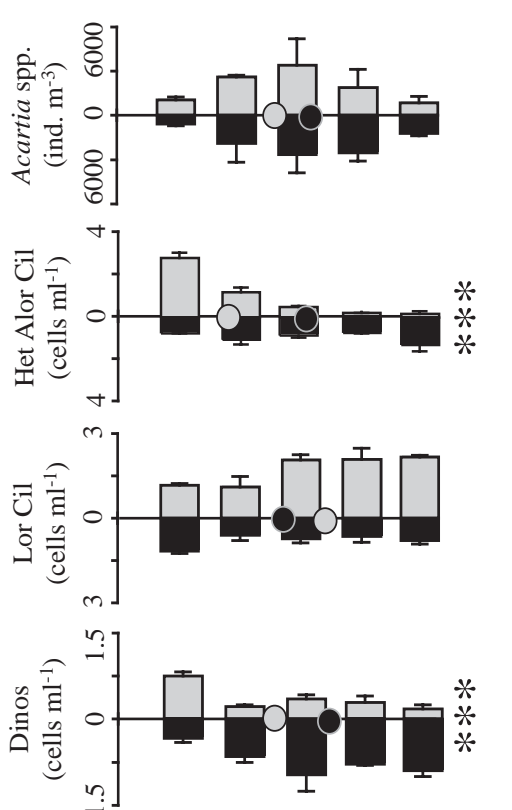

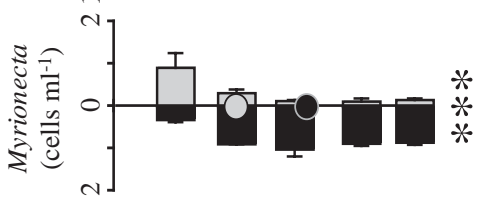
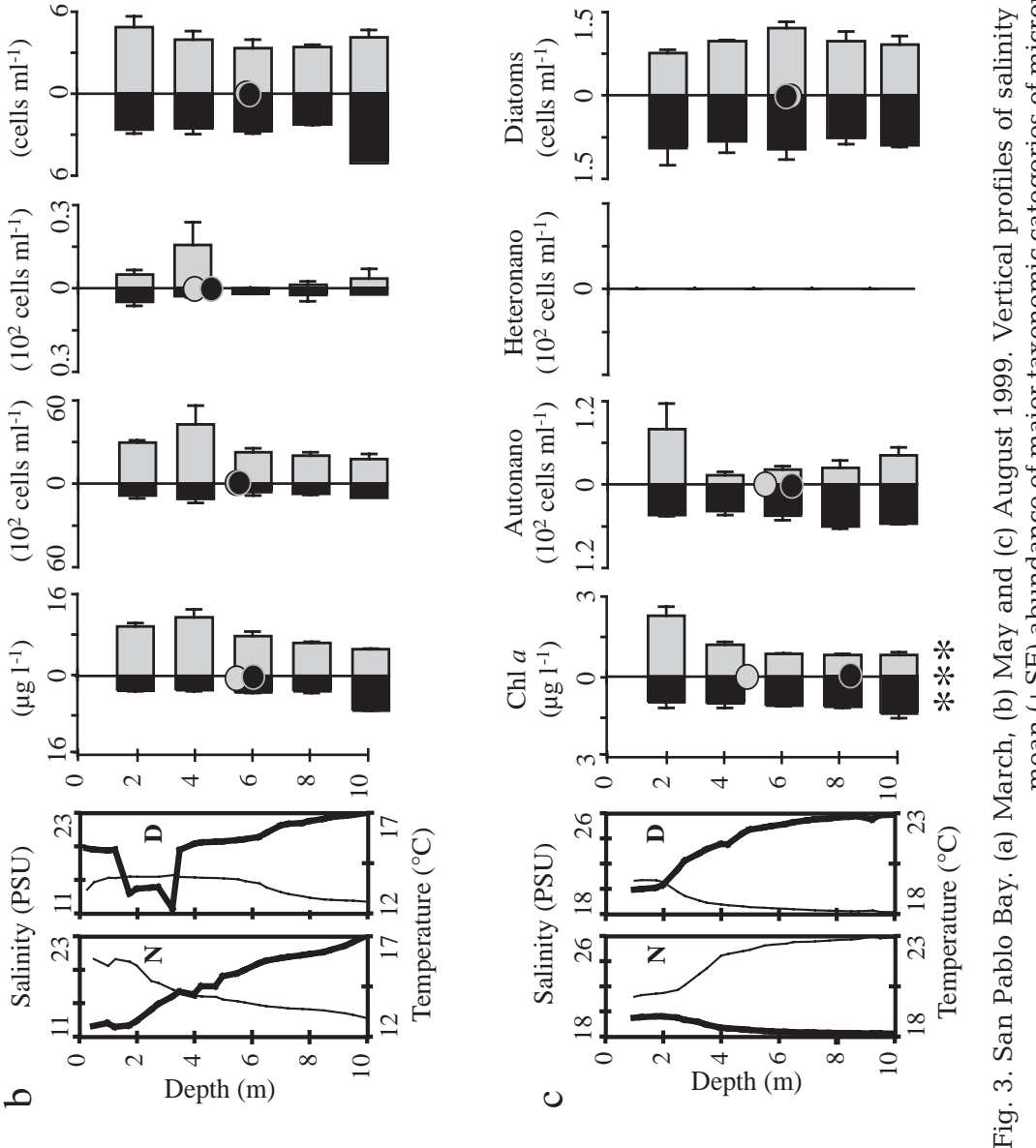
\begin{tabular}{l|l|}
0 & 0 \\
0 \\
0
\end{tabular}
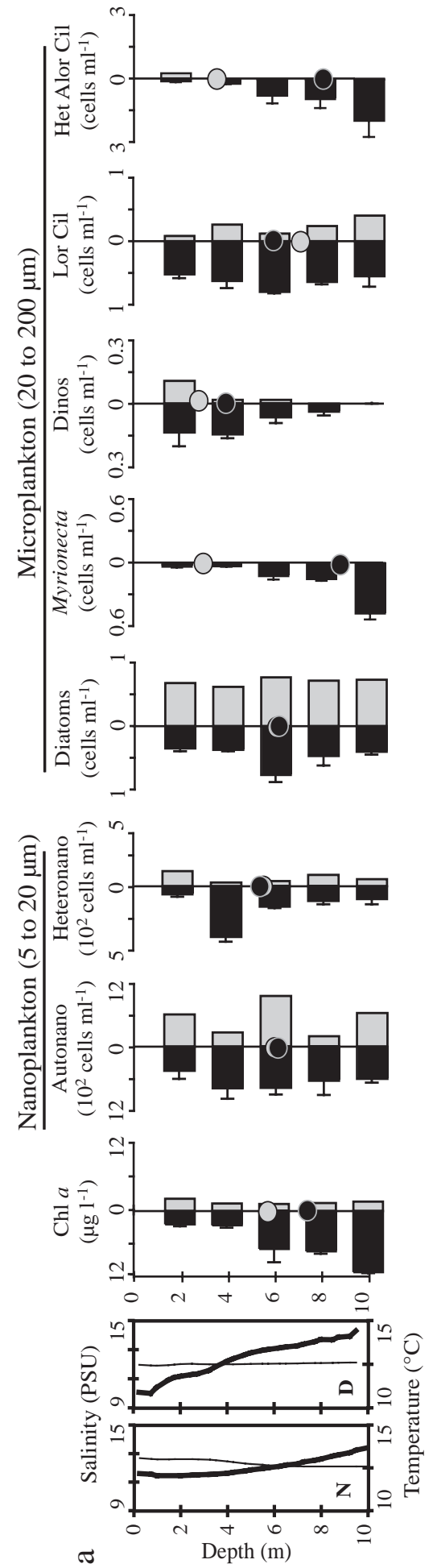
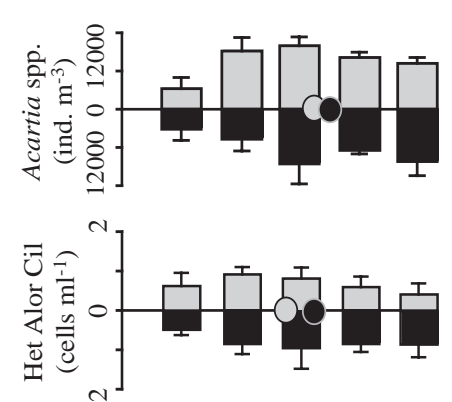

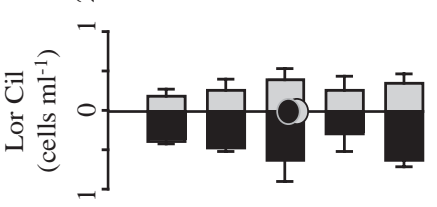
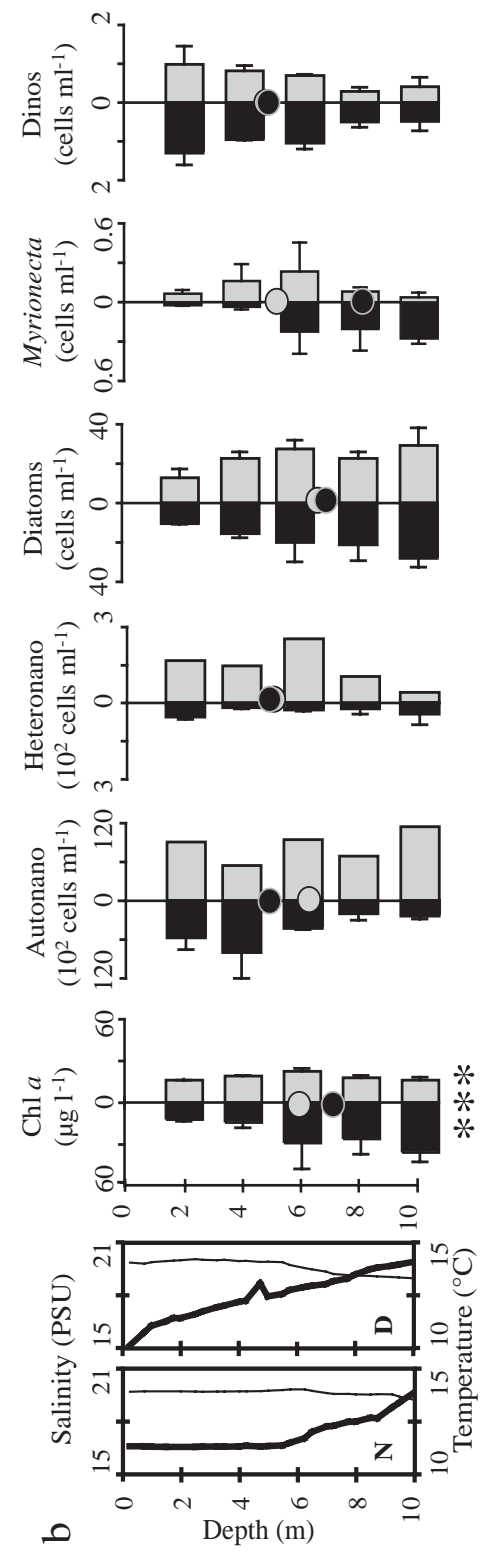

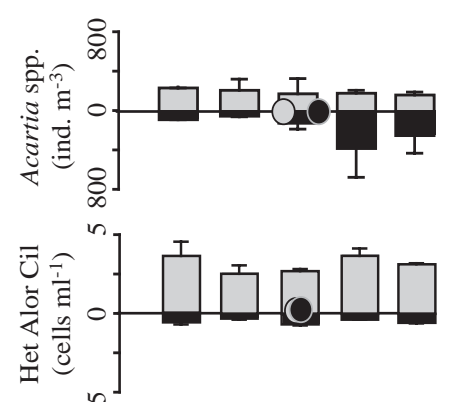

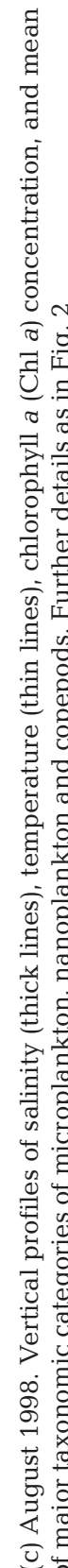
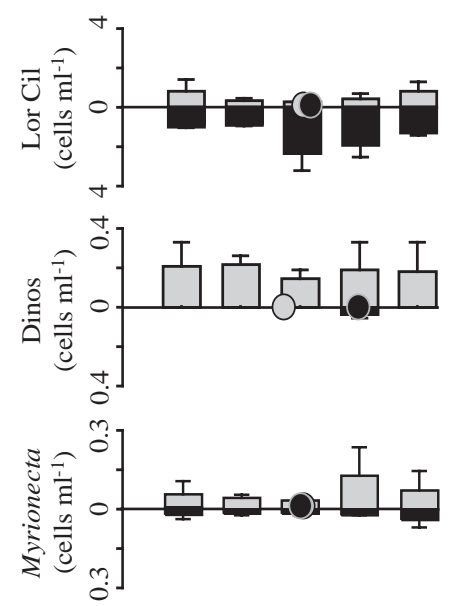

I
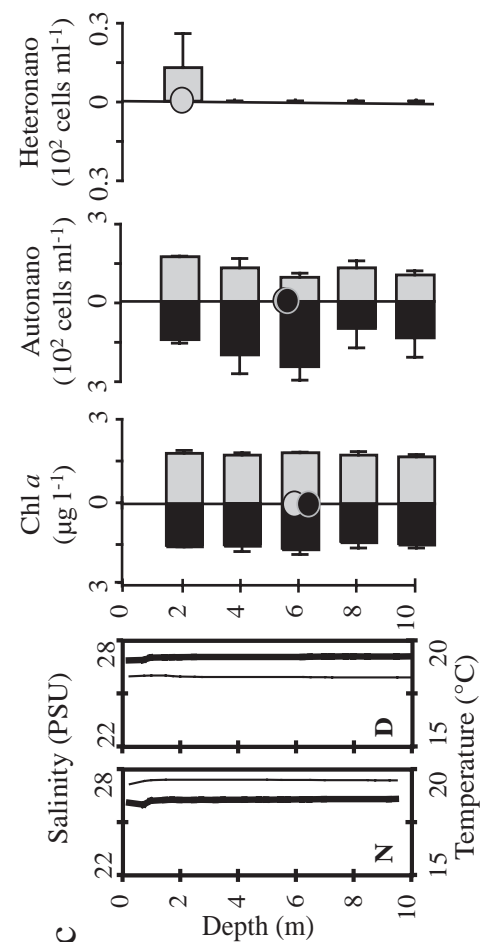

竞 

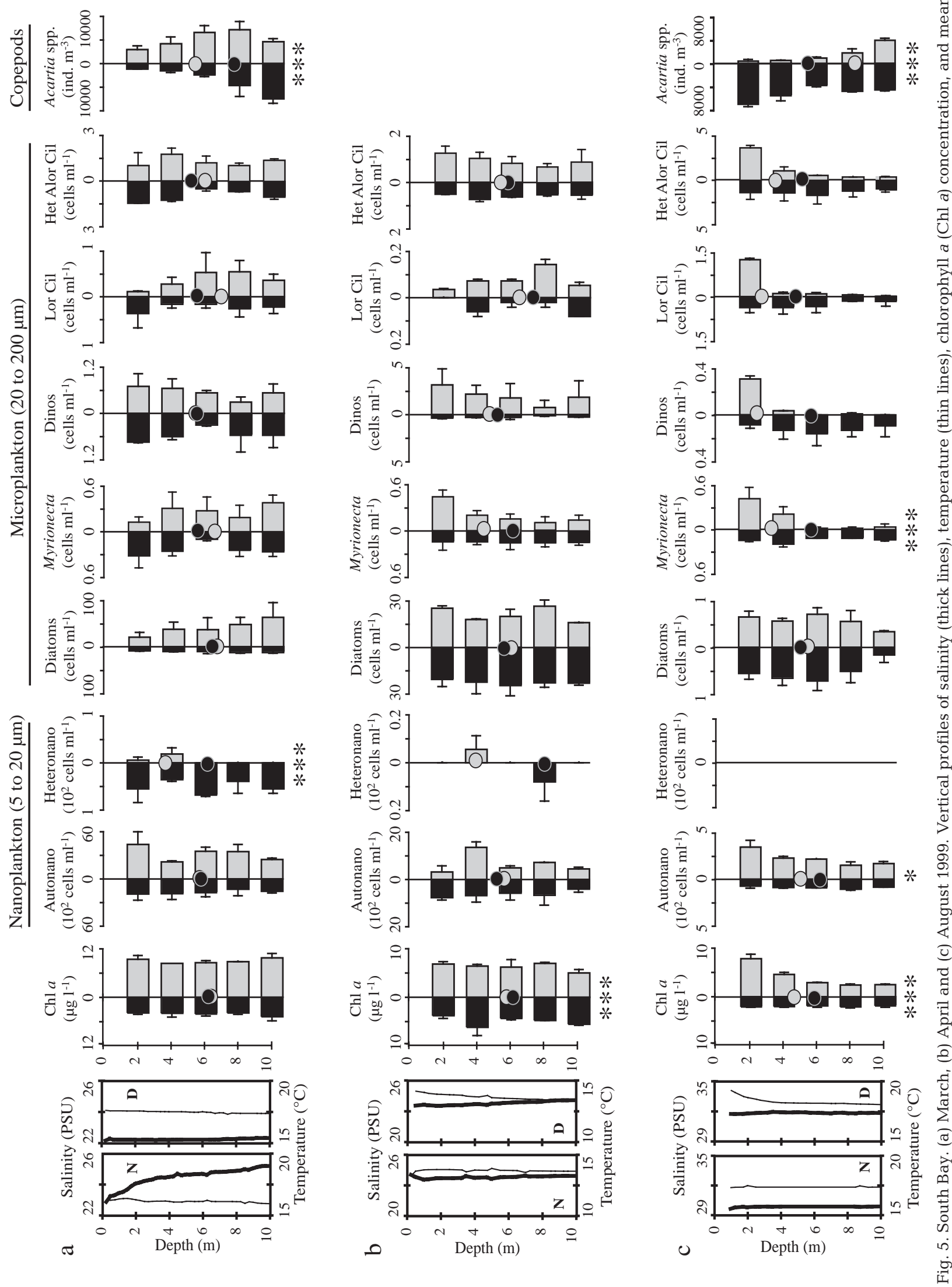
Interannual patterns

Hydrography. There was no significant difference in the stratification index between 1998 and 1999 in San Pablo Bay; however, the stratification index was significantly higher during 1998 than 1999 in South Bay ( $\mathrm{p}<<0.001$ ) (Table 3).

Plankton distributions. Several taxa showed significant interannual differences in weighted mean depths in both San Pablo Bay and South Bay (Table 4), and in all cases these taxa were concentrated deeper in the water column during 1999 and shallower during 1998 (Figs. 2 to 5). This was especially true for heterotrophic/mixotrophic aloricate ciliates, whose mean depths were deeper in 1999 in both bays. In addition, Myrionecta rubra and heterotrophic nanoflagellates were found deeper only in San Pablo Bay (Figs. 2 \& 3), and diatoms were observed deeper in South Bay in 1999 (Figs. 4 \& 5).

\section{Correlation of plankton vertical distributions with abiotic and biotic factors}

\section{Abiotic factors}

There was no significant correlation, either positive or negative, between weighted mean depth of any micro- or nanoplankton taxa and the stratification index $(\Delta \mathrm{S})$ in any comparison when the entire data set was analyzed. However, there were rare instances of significant correlation between the stratification index and isolated taxa when the data were sorted by location. For instance, when weighted mean depths were compared with the stratification index within San Pablo Bay, the only significant correlation observed was for heterotrophic/mixotrophic aloricate ciliates, which were concentrated deeper when stratification was stronger, although the correlation was weak ( $\mathrm{r}=$ 0.47, $\mathrm{p}=0.029 ; \mathrm{n}=22$ ). Conversely, when the data were sorted by season within San Pablo Bay, a strong correlation was observed between $\Delta \mathrm{S}$ and loricate ciliates ( $\mathrm{r}=0.90, \mathrm{p}=0.002, \mathrm{n}=8)$, which were deeper in the water column when stratification was higher during the dry seasons of 1998 and 1999.

In South Bay, the water column was relatively wellmixed during nearly every sampling period, with $\Delta \mathrm{S}$ rarely exceeding $1.0 \mathrm{ppt}$ (Table 3 ). During the very wet spring of 1998, however, $\Delta \mathrm{S}$ reached 5.0 ppt. However, despite the relatively strong stratification in spring 1998, there were no significant correlations between the weighted mean depths of micro- or nanoplankton taxa and $\Delta \mathrm{S}$ in South Bay, with the sole exception of large $(>20 \mu \mathrm{m})$ dinoflagellates, which clustered shallower in the water column when $\Delta \mathrm{S}$ was higher during wet season, non-bloom periods (March 1998 and April 1999) ( $\mathrm{r}=-0.84, \mathrm{p}=0.019, \mathrm{n}=8)$.

\section{Biotic factors}

In addition to abiotic factors such as water column stratification, predation could also have influenced the vertical distributions of micro- and nanoplankton. We identified 2 potential classes of planktonic predators: (1) mesozooplankton (200 to $2000 \mu \mathrm{m})$, and (2) heterotrophic microplankton (20 to $200 \mu \mathrm{m})$.

Mesozooplankton predators. The 3 most commonly occurring mesozooplankton taxa in our samples were copepods, specifically the calanoid copepod group Acartia spp. (most abundant), and 2 cyclopoid copepod taxa, Oithona davisae and Limnoithona tetraspina (both present in relatively low abundance).

Table 4. p-values from 2-way ANOVA tests for temporal variability in stratification index and weighted mean depths of microplankton (20 to $200 \mu \mathrm{m}$ ) and nanoplankton (5 to $20 \mu \mathrm{m})$ collected from San Pablo Bay and South Bay, San Francisco Estuary. Bold represents significant differences $\left({ }^{*} \mathrm{p}<0.05 ;{ }^{* *} \mathrm{p}<0.01 ;{ }^{* * *} \mathrm{p}<0.001\right)$

\begin{tabular}{|c|c|c|}
\hline & $\begin{array}{c}\text { Seasonal } \\
\text { (wet vs. dry) }\end{array}$ & $\begin{array}{c}\text { Interannnual } \\
\text { (1998 vs. 1999) }\end{array}$ \\
\hline \multicolumn{3}{|l|}{ San Pablo Bay } \\
\hline Stratification $(\Delta \mathbf{S})$ & $0.001^{* * *}$ & 0.551 \\
\hline Chlorophyll a & 0.616 & 0.997 \\
\hline \multicolumn{3}{|l|}{ Microplankton } \\
\hline Loricate ciliates & 0.180 & 0.663 \\
\hline Aloricate ciliates & $0.015^{*}$ & $\mathbf{0 . 0 1 3}^{*}$ \\
\hline Myrionecta rubra & $0.027^{*}$ & $0.005^{* *}$ \\
\hline Diatoms & 0.150 & 0.758 \\
\hline Dinoflagellates & 0.631 & 0.111 \\
\hline \multicolumn{3}{|l|}{ Nanoplankton } \\
\hline Nanodiatoms & 0.130 & 0.126 \\
\hline Nanodinoflagellates & 0.909 & 0.059 \\
\hline Autonanoflagellates & 0.300 & 0.075 \\
\hline Heteronanoflagellates & 0.099 & $0.032^{*}$ \\
\hline \multicolumn{3}{|l|}{ South Bay } \\
\hline Stratification $(\Delta \mathbf{S})$ & $0.002^{* *}$ & $0.000^{* * *}$ \\
\hline Chlorophyll a & $0.010^{* *}$ & $0.002^{* *}$ \\
\hline \multicolumn{3}{|l|}{ Microplankton } \\
\hline Loricate ciliates & $0.026^{*}$ & 0.170 \\
\hline Aloricate ciliates & 0.199 & $\mathbf{0 . 0 3 3}^{*}$ \\
\hline Myrionecta rubra & 0.333 & 0.070 \\
\hline Diatoms & $0.000^{* * *}$ & $0.041^{*}$ \\
\hline Dinoflagellates & 0.305 & 0.625 \\
\hline \multicolumn{3}{|l|}{ Nanoplankton } \\
\hline Nanodiatoms & 0.168 & 0.678 \\
\hline Nanodinoflagellates & 0.148 & 0.079 \\
\hline Autonanoflagellates & 0.337 & 0.418 \\
\hline Heteronanoflagellates & 0.219 & 0.699 \\
\hline
\end{tabular}


Of the 3 copepod taxa, the vertical distribution of Acartia spp. (weighted mean depth, WMD) showed the greatest degree of correlation with that of micro- and nanoplankton. In particular, Acartia spp. distribution was strongly (r between 0.6 and 0.8 ) positively correlated with that of loricate and aloricate ciliates and heterotrophic flagellates during 1998 across both bays and all seasons. Correlations on a seasonal and diel basis were less consistent, with a small number of negative correlations observed in dry seasons and daytime samples, and 1 positive correlation during wet seasonbloom periods. On a regional basis, Acartia spp. distribution was relatively strongly ( $\mathrm{r} \sim 0.5$ to 0.6 ) positively correlated with those of aloricate ciliates and $<20 \mu \mathrm{m}$ dinoflagellates in San Pablo Bay. However in South Bay, Acartia spp. WMD was significantly correlated only with that of nanoflagellates, being negatively correlated with pigment-containing nanoflagellates and positively correlated with the distribution of nonpigment-containing nanoflagellates (Table 5).

The WMD of Oithona davisae was consistently negatively correlated with that of $<20 \mu \mathrm{m}$ diatoms (chiefly Skeletonema spp.), particularly in San Pablo Bay during the daytime and during dry season periods in 1998. Conversely, $O$. davisae WMD was strongly ( $\mathrm{r} \sim 0.6$ to 0.8 ) positively correlated with that of non-Myrionecta aloricate ciliates in San Pablo Bay during 1998 (Table 5).

Finally, of the 3 copepod taxa, Limnoithona tetraspina distribution showed the fewest significant correlations with those of micro- or nanoplankton. However, in South Bay, the WMD of $L$. tetraspina was very strongly $(\mathrm{r} \sim 0.9)$ correlated with that of aloricate ciliates (Table 5).

Microplankton predators. Our results revealed many significant correlations between the vertical distribution of nanoplankton and 3 micro- plankton predator groups: (1) loricate ciliates, primarily the genera

Table 5. Weighted mean depth (WMD) of copepod predators vs. WMD of prey. Pearson's correlation coefficients for comparisons between WMD of Acartia spp., Oithona davisae and Limnoithona tetraspina, and WMD of major categories of nano- and microplankton prey taxa. Lor cil: loricate ciliates; Het Alor: heterotrophic/mixotrophic aloricate ciliates; Myrio: Myrionecta rubra; Diat: diatoms; Dino: dinoflagellates; Aflag: autotrophic nanoflagellates; Hflag: heterotrophic nanoflagellates. ${ }^{*} \mathrm{p}<0.05$; ${ }^{* *} \mathrm{p}<0.01 ;{ }^{* * *} \mathrm{p}<0.001 ;-$ : non-significant correlations

\begin{tabular}{|c|c|c|c|c|c|c|c|c|c|c|c|}
\hline \multirow[t]{2}{*}{ Predator } & \multicolumn{6}{|c|}{ Microplankton (20 to $200 \mu \mathrm{m})$} & \multicolumn{5}{|c|}{ Nanoplankton (5 to $20 \mu \mathrm{m})$} \\
\hline & Lor cil & Het Alor & Myrio & Diat & Dino & Total & Diat & Dino & Aflag & Hflag & Total \\
\hline \multicolumn{12}{|l|}{ Acartia spp. } \\
\hline All data & - & - & - & - & - & - & $-0.40^{*}$ & - & - & - & - \\
\hline 1998 & $0.77^{* * *}$ & $0.60^{*}$ & - & $0.54^{*}$ & - & $0.65^{* *}$ & - & - & - & $0.82^{*}$ & - \\
\hline 1999 & $-0.51^{*}$ & - & - & - & - & - & - & - & - & - & - \\
\hline Wet season, bloom & - & - & - & - & $0.63^{* *}$ & - & - & - & - & - & - \\
\hline Dry season & - & - & $-0.57^{*}$ & - & - & - & - & - & - & - & - \\
\hline Day & $-0.68^{* *}$ & - & - & - & $-0.61^{*}$ & - & - & - & - & - & - \\
\hline Night & - & - & - & - & - & - & - & - & - & - & - \\
\hline San Pablo Bay & - & $0.53^{*}$ & - & - & - & $0.50^{*}$ & - & $0.55^{*}$ & - & - & - \\
\hline South Bay & - & - & - & - & - & - & - & - & $-0.64^{* *}$ & $0.86^{* *}$ & \\
\hline \multicolumn{12}{|l|}{ Oithona davisae } \\
\hline All data & - & $0.43^{*}$ & - & - & - & - & $-0.50^{* *}$ & - & - & - & - \\
\hline 1998 & $0.77^{* * *}$ & $0.66^{* *}$ & - & - & - & $0.59^{*}$ & $-0.52^{*}$ & - & - & - & - \\
\hline 1999 & - & - & - & - & - & - & - & - & - & - & - \\
\hline Wet season, bloom & - & - & - & - & - & - & - & - & - & - & - \\
\hline Dry season & - & - & - & - & - & - & $-0.65^{* *}$ & - & - & - & - \\
\hline Day & - & - & - & - & - & - & $-0.68^{* *}$ & - & - & - & - \\
\hline Night & - & - & - & - & - & - & - & - & - & - & - \\
\hline San Pablo Bay & - & $0.77^{* *}$ & - & - & $0.59^{*}$ & $0.62^{*}$ & $-0.69^{*}$ & - & - & - & - \\
\hline South Bay & - & - & - & - & - & - & - & - & - & $0.80^{*}$ & - \\
\hline \multicolumn{12}{|c|}{ Limnoithona tetraspina } \\
\hline All data & - & - & - & - & - & - & - & - & $0.45^{*}$ & - & - \\
\hline 1998 & - & - & - & - & - & - & - & - & - & - & - \\
\hline 1999 & - & - & - & - & - & - & - & - & - & - & - \\
\hline Wet season, bloom & - & - & - & - & - & - & $-0.73^{* *}$ & - & - & - & $-0.71^{*}$ \\
\hline Dry season & - & - & - & - & - & - & - & - & - & - & $0.66^{*}$ \\
\hline Day & - & - & - & - & - & - & - & - & - & - & - \\
\hline Night & - & - & - & - & - & - & - & - & - & - & $-0.61^{*}$ \\
\hline San Pablo Bay & - & - & - & - & - & - & - & - & - & - & - \\
\hline South Bay & - & $0.89^{*}$ & $0.90^{*}$ & - & - & $0.84^{*}$ & - & - & - & - & - \\
\hline
\end{tabular}


Tintinnopsis, Eutintinnus and Codonellopsis; (2) heterotrophic/mixotrophic aloricate ciliates, mostly the genera Strombidium and Strobilidium; (3) heterotrophic dinoflagellates, in particular the genera Protoperidinium and Gymnodinium.

The vertical distribution of all 3 groups of microplankton consumers showed significant positive correlations with chlorophyll a distribution. In particular, each group was most closely correlated with chlorophyll during the daytime, and only during 1999. In addition, both loricate ciliate and heterotrophic/ mixotrophic aloricate ciliate distributions were aligned with chlorophyll concentration in South Bay, with aloricate ciliates further correlated most strongly during the dry season (Table 6).

With respect to correlations between microplankton consumers and potential nanoplankton prey taxa, aloricate ciliates and dinoflagellates exhibited the highest frequency of significant correlation with nanoplankton distribution, with only weak and infrequent significant correlations between loricate ciliates and nanoplankton. In particular, the vertical distribution of both aloricate ciliates and dinoflagellates was consistently positively correlated with that of autotrophic nanoflagellates on a diel, seasonal, interannual and regional basis. Also, the distribution of heterotrophic dinoflagellate distribution was often positively correlated with that of heterotrophic nanoflagellates, alternating between positive correlation with the autotrophic nanoflagellates during the dry season and heterotrophic nanoflagellates during the wet season, non-bloom periods. The vertical distribution of heterotrophic dinoflagellate was also negatively correlated with that of $<20 \mu \mathrm{m}$ diatoms, especially in South Bay during 1999 (Table 6).

\section{DISCUSSION}

The 4-way analysis of variance on the WMD of micro- and nanoplankton taxa produced several important results. First, the microplankton taxa, and more specifically the ciliates, showed the greatest variability in vertical distribution during the course of this study. The WMD of nanoplankton taxa generally did not vary consistently according to day vs. night, season, year or location within the SFE. Second, the most significant differences in the vertical distribution of microplankton were observed on a seasonal basis, and to a lesser extent on the basis of time of day and year. Location within the SFE appeared to have much less effect on how microplankton taxa were distributed in the water column. Finally, the heterotrophic/mixotrophic aloricate ciliates (except Myrionecta rubra) displayed the most significant differences in vertical distribution on all time scales, with

Table 6. Weighted mean depth (WMD) of heterotrophic microplankton predators vs. WMD of prey. Pearson's correlation coefficients for comparisons between WMD of loricate ciliates, aloricate ciliates and dinoflagellates and WMD of major categories of potential nanoplankton prey taxa. Dinoflag: dinoflagellates; Aflag: autotrophic nanoflagellates; Hflag: heterotrophic nanoflagellates. ${ }^{*} \mathrm{p}<0.05 ;{ }^{* *} \mathrm{p}<0.01 ;{ }^{* * *} \mathrm{p}<0.001 ;-$ : non-significant correlations

\begin{tabular}{|c|c|c|c|c|c|c|}
\hline \multirow[t]{2}{*}{ Predator } & \multicolumn{6}{|c|}{ Nanoplankton (5 to $20 \mu \mathrm{m}$ ) } \\
\hline & Chl a & Diatoms & Dinoflag & Aflag & Hflag & Total \\
\hline \multicolumn{7}{|l|}{ Loricate ciliates } \\
\hline All data & $0.30^{*}$ & - & - & $0.29^{*}$ & - & - \\
\hline 1998 & - & - & - & - & - & - \\
\hline 1999 & $0.49^{*}$ & - & - & - & - & - \\
\hline $\begin{array}{l}\text { Wet season, } \\
\text { bloom }\end{array}$ & - & - & - & - & - & - \\
\hline $\begin{array}{c}\text { Wet season, } \\
\text { non-bloom }\end{array}$ & - & - & - & - & $0.57^{*}$ & - \\
\hline Dry season & - & - & - & - & - & - \\
\hline Day & $0.58^{* *}$ & - & - & - & - & - \\
\hline Night & - & - & - & - & - & - \\
\hline San Pablo Bay & - & - & - & - & - & - \\
\hline South Bay & $0.49^{*}$ & - & - & $0.43^{*}$ & - & - \\
\hline \multicolumn{7}{|l|}{ Aloricate ciliates } \\
\hline All data & $0.48^{* * *}$ & - & $0.35^{*}$ & $0.60^{* * *}$ & - & 0.35 \\
\hline 1998 & - & - & - & - & - & - \\
\hline 1999 & $0.63^{* * *}$ & - & - & $0.75^{* * *}$ & - & - \\
\hline $\begin{array}{l}\text { Wet season, } \\
\text { bloom }\end{array}$ & $0.50^{*}$ & - & $0.65^{*}$ & $0.60^{*}$ & - & - \\
\hline $\begin{array}{c}\text { Wet season, } \\
\text { non-bloom }\end{array}$ & - & $0.65^{* *}$ & - & $0.53^{*}$ & - & - \\
\hline Dry season & $0.88^{* * *}$ & - & - & $0.74^{* * *}$ & - & - \\
\hline Day & $0.50^{*}$ & - & - & $0.64^{* * *}$ & - & - \\
\hline Night & - & $0.59^{* *}$ & - & - & - & $0.46^{*}$ \\
\hline San Pablo Bay & - & - & - & $0.68^{* * *}$ & - & $0.51^{* *}$ \\
\hline South Bay & $0.86^{* * *}$ & - & - & $0.47^{*}$ & - & - \\
\hline \multicolumn{7}{|l|}{ Dinoflagellates } \\
\hline All data & $0.32^{*}$ & - & $0.38^{*}$ & $0.51^{* * *}$ & $0.42^{*}$ & - \\
\hline 1998 & - & $-0.55^{*}$ & - & - & - & - \\
\hline 1999 & $0.65^{* * *}$ & - & - & $0.54^{* *}$ & - & $0.48^{*}$ \\
\hline $\begin{array}{l}\text { Wet season, } \\
\text { bloom }\end{array}$ & - & - & $0.54^{*}$ & - & - & - \\
\hline $\begin{array}{r}\text { Wet season, } \\
\text { non-bloom }\end{array}$ & - & - & - & - & $0.67^{*}$ & - \\
\hline Dry season & $0.73^{* * *}$ & - & - & $0.67^{* *}$ & - & - \\
\hline Day & $0.46^{*}$ & - & - & - & - & - \\
\hline Night & - & - & - & $0.48^{*}$ & $0.60^{*}$ & - \\
\hline San Pablo Bay & - & - & - & $0.48^{*}$ & $0.71^{* *}$ & - \\
\hline South Bay & - & $-0.61^{* *}$ & - & $0.61^{* *}$ & - & - \\
\hline
\end{tabular}


the other major taxa groups (loricate ciliates, $M$. rubra, diatoms and dinoflagellates) varying only with respect to season.

The ANOVA results provided a valuable base on which to make a more focused examination of temporal patterns in the vertical distributions of ciliates, as well as a framework for the discussion of the potential influence of hydrography (i.e. salinity stratification) and planktonic predators on the observed trends.

\section{Temporal patterns in ciliate vertical distribution}

\section{Seasonal and interannual cycles}

Non-Myrionecta aloricate ciliates were generally distributed at a deeper depth in 1998 than in 1999, but significant interannual differences in vertical distribution were few and showed no consistent pattern as a function of location, season or time of day. Conversely, there were frequent seasonal differences in aloricate ciliate WMD in both South Bay and San Pablo Bay during 1998 and 1999, as well as during daytime and nighttime. Similarly, loricate ciliates displayed no interannual differences in vertical distribution, and only limited seasonal differences in WMD. In general, loricate ciliates were found deeper during the wet season than during the dry season, but only in daytime samples during 1999 in South Bay.

The lack of consistent interannual or seasonal trends in vertical distribution among any ciliate taxa in the SFE is somewhat unexpected, given the substantial climatic and hydrographic differences between years (1998 vs. 1999) and seasons (wet vs. dry). The 1997 to 1998 ENSO event produced record rainfall in the Bay area during winter/spring 1998, leading to substantial salinity stratification in the SFE. The lack of an interannual trend is particularly surprising for San Pablo Bay, where freshwater flow is such a dominant physical force. Seasonal trends in ciliate vertical distribution have been documented in the coastal ocean and in lakes, although published reports of seasonal cycles in ciliate vertical distribution in other estuarine systems are extremely limited.

For instance, in the only study known to us that explicitly examined vertical distributions in an estuary over a full year, Dolan \& Coats (1990) found ciliates in Chesapeake Bay to be concentrated primarily near the bottom during the spring, but concentrated in surface waters during the summer and autumn. In the Damariscotta River estuary in Maine, testing for differences in vertical distribution on a seasonal basis was not a stated goal; however, Sanders (1987) reported qualitative differences in the vertical distribution of loricate and aloricate ciliates during 1981. Maximum loricate ciliate abundance was deep ( 20 m) in the water column in March, at intermediate depths $(\sim 7 \mathrm{~m})$ in July, and near the surface ( 0 to $7 \mathrm{~m}$ ) in September and December. Aloricate ciliates also followed the same general trend (Sanders 1987, present Table 2).

Seasonal patterns in ciliate vertical distribution were also inferred from studies conducted in marine coastal regions. In Kastela Bay (central Adriatic Sea), aloricate ciliates showed a bimodal distribution in March (local maxima in abundance at 5 and $25 \mathrm{~m}$ ), and were highly concentrated (5 m) in May, and aloricate ciliate vertical distributions were more homogeneous during summer and fall (Bojanic et al. 2001, their Fig. 3). However, during the same study loricate ciliates were found exclusively above $10 \mathrm{~m}$ in the spring (February to May) but were concentrated at $15 \mathrm{~m}$ during October (Bojanic et al. 2001, their Fig. 5).

Evidence for seasonal variability among ciliate distributions has also been documented for temperate freshwater lakes. Pace (1982) observed the distributions of both loricate and heterotrophic aloricate ciliates to be uniform with depth during the winter in a small lake in Georgia, but to be mostly in the surface layer during the spring. Similarly, in a French humic lake, aloricate ciliates were distributed evenly through the water column during April, but were substantially more abundant between 0 and $5 \mathrm{~m}$ in June and between 10 and $15 \mathrm{~m}$ in October (Carrias et al. 1994).

These reports of marked seasonal variability in ciliate vertical distribution contrast with our results of far fewer seasonal differences in the SFE.

Diel cycles

In the SFE, diel differences in vertical distribution occurred even less frequently than seasonal differences; however, in nearly every case, the WMD of ciliates was deeper during the night than during the day, and the qualitative patterns of daytime and nighttime vertical distributions were generally more consistent.

For example, in San Pablo Bay, non-Myrionecta aloricate ciliates showed diel differences in WMD in 4 of 6 sampling periods, and in every case the organisms were highly concentrated near the surface during the day but distributed throughout the water column during the night (Figs. $2 \& 3$ ). Heterotrophic/mixotrophic aloricate ciliates (except $M$. rubra) only showed a diel difference in vertical distribution in South Bay during August 1999; however, the pattern was the same as in San Pablo Bay, with a daytime peak at $2 \mathrm{~m}$ and a more homogeneous distribution during the night (Fig. 5).

The unusual mixotrophic aloricate ciliates Myrionecta rubra were only observed to have significantly different vertical distributions between day and night 
on 2 occasions throughout the study period, during April 1998 and August 1999 in South Bay. Loricate ciliates showed differences in diel vertical distribution only during the dry season, and primarily in San Pablo Bay, although in one case WMD was deeper during the night and in the other WMD was deeper during the day.

Whereas the lack of a consistent seasonal change in vertical distribution in the SFE contrasted with other temperate systems, on a diel basis ciliate vertical distribution in the SFE appears to fall within the wide range of patterns observed elsewhere. Strong swimming capabilities have been observed in the laboratory for a range of ciliate taxa (Jonsson 1989, Jonsson \& Tiselius 1990); however, in the field ciliates have been observed to migrate vertically in some systems and not in others. Several, but not all, heterotrophic ciliates were found to migrate toward the surface during the day in a Norwegian fjord (Dale 1987). And Favella sp., a loricate ciliate, was found near the surface in the morning and near the bottom at night during 2 separate $28 \mathrm{~h}$ periods in a small tidal estuary in Massachusetts (Stoecker et al. 1984). Diel vertical migration among heterotrophic aloricate ciliates was also documented in the NW Mediterranean Sea, although in an opposite pattern, with ciliates migrating toward the surface at night (Perez et al. 2000). However, no diel vertical migrations were observed among ciliates over two $48 \mathrm{~h}$ sampling periods in the northern Adriatic Sea (Revelante \& Gilmartin 1990).

Similarly, there is a lack of consensus as to when and under what conditions Myrionecta rubra may vertically migrate. In the laboratory, the swimming speed of $M$. rubra was as high as $8.5 \mathrm{~mm} \mathrm{~s}^{-1}$ (Lindholm 1985, Jonsson \& Tiselius 1990), and diel vertical migration of $M$. rubra has been demonstrated in a wide range of marine environments, including a Norwegian fjord (Dale 1987), an estuary in NW Spain (Villarino et al. 1995), and the Baltic Sea (Passow 1991, Olli et al. 1998).

However, a number of investigations into the behavior of Myrionecta rubra have shown that vertical migration of this phototrophic ciliate may be quite variable. For instance, the vertical distribution of $M$. rubra was not related to the time of day in the NW Mediterranean Sea (Dolan \& Marrasé 1995) or a brackish inlet on the coast of Finland (Crawford \& Lindholm 1997). Crawford \& Purdie (1992) have suggested that turbulence may be the major cue for vertical migration of $M$. rubra to maintain position in estuaries, while others propose that migration of these ciliates is a response to light levels (Lindholm \& Mork 1990, Passow 1991).

Thus, the lack of a strong seasonal pattern in vertical distribution along with no evidence of diel migration behavior among Myrionecta rubra in the SFE suggests that other factors besides seasonal changes and time of day may influence its distribution.

\section{Factors influencing vertical distributions in the SFE}

\author{
Stratification
}

We did not observe any consistent correlation between the degree of stratification in the water column and the WMD of micro- or nanoplankton. Explicit examinations in estuaries of protozoan vertical distributions in relation to hydrography are very few. However, in a highly stratified Norwegian fjord, Andersen \& Nielsen (2002) similarly found the vertical distribution of ciliates to be only marginally affected by the presence of a large salinity gradient, although not all ciliate taxa showed the same salinity tolerances.

In the coastal ocean, on the other hand, stratification and other physical conditions have been shown to exert measurable influence on ciliate vertical distribution. In the northern Aegean Sea, ciliates were found to cluster near the surface only under stratified conditions, whereas their vertical distribution was homogeneous with depth when the water column was wellmixed (Pitta \& Giannakourou 2000). In addition, Montagnes et al. (1999) observed both finescale (cm) and microscale $(\mathrm{m})$ patchiness in ciliate vertical distributions in the Irish Sea, and attributed much of these patterns to hydrographic features such as fronts and pycnoclines. Finally, ciliate vertical distribution of ciliates was also strongly related to the pycnocline depth off the west coast of New Zealand, with high and consistently negative correlations between ciliates and water density (sigma- $t$ ) at all stations sampled (James \& Hall 1995). However, the ciliates in the $\mathrm{New}$ Zealand study were also highly positively correlated with chlorophyll and picophytoplankton abundance throughout the water column, suggesting that both physical and biological variables may have affected their distribution.

\section{Predation}

In the present study, the significant correlations observed between the vertical distribution of copepod predators and potential microplankton prey, as well as between microplankton consumers and potential nanoplankton prey, suggest that in the SFE predatorprey interactions may have more influence on the distribution of plankton than stratification in the water column.

Acartia spp. were the most abundant copepods in both San Pablo Bay and South Bay during our study period, and also showed the highest incidence of significant correlation with the vertical distribution of microplankton taxa, in particular heterotrophic aloricate ciliates (Table 5). It is interesting, however, that 
the correlations were both positive and negative for the same microplankton taxa during different time periods. Closer examination of the data revealed that the negative correlations between Acartia spp. and several microplankton taxa were driven largely by dramatic differences in daytime vertical distributions in South Bay during August 1999 (Fig. 5c). When these 2 replicate daytime casts were removed from the analyses, virtually all the negative correlations disappeared. Moreover, removal of these casts and reanalysis of the entire data set resulted in additional significant positive correlations between Acartia spp. and total microplankton (specifically non-Myrionecta aloricate ciliates, diatoms and dinoflagellates).

Correlations were also quite strong between the vertical distribution of microplankton consumer taxa (loricate ciliates, aloricate ciliates and dinoflagellates) and their potential food resources (chlorophyll $a$ and nanoflagellates) in the SFE (Table 6). Of particular note is the fact that the vertical distribution of nonMyrionecta aloricate ciliates was correlated with chlorophyll only during periods when they were not statistically related to the distribution of Acartia spp.

To our knowledge, the only other published studies to specifically test the relationship between the vertical distribution of copepods and ciliates in estuaries have been conducted in Norwegian fjords. Titelman \& Tiselius (1998) found the abundance of copepods (mostly Pseudocalanus sp. but also Acartia spp.) to correlate weakly with chlorophyll a on only 1 of 4 sampling dates during spring 1996 in the Gullmarsfjorden, but never to correlate with ciliate abundance. However in the Hylsfjorden, several copepod taxa (including $A$. longiremis and Oithona spp.) showed significant positive correlations with potential food (mostly loricate ciliate abundance) (Andersen \& Nielsen 2002).

The relationship between the vertical distribution of ciliates and their potential food resources has been studied more frequently, and a significant relationship between their distributions appears to be common in many aquatic systems. In estuaries, the vertical distribution of heterotrophic ciliates was positively correlated with that of heterotrophic flagellates in the Chesapeake Bay (Dolan \& Coats 1990), while in Narragansett Bay the vertical distribution of certain loricate ciliates (Tintinnopsis minuta, Stenosemella spp.) was highly correlated with chlorophyll concentration (Verity 1987). In oceanic waters, the vertical distribution of ciliates was also closely related to the distribution of chlorophyll in the Catalan Sea, NW Mediterranean (Dolan \& Marrasé 1995), in the Adriatic Sea (Revelante \& Gilmartin 1990), and in several locations in the western Pacific (Suzuki \& Taniguchi 1998). Ciliate distributions have also been found to be closely associated with both chlorophyll and microbial food resources in a number of freshwater lakes (Pace 1982, Carrias et al. 1994, Zingel \& Ott 2000).

The fact that Acartia spp. distribution was not correlated more frequently with that of microplankton prey suggests that additional factors other than prey foraging may have affected copepod distribution, such as avoidance of predators (e.g. Bollens \& Frost 1989, 1991) or position maintenance in the estuary (e.g. Laprise \& Dodson 1994, Kimmerer et al. 1998). Titelman \& Tiselius (1998) suggested that the vertical distribution of copepods would only be correlated with that of their food resources when moderately food limited; under either severe food limitation or food saturating conditions, copepods would lack the motivation to search and aggregate around food patches.

Measurements of the specific ingestion rates and prey selectivity of Acartia spp. in both San Pablo Bay and South Bay during 2000 showed that non-Myrionecta ciliates were always a significant proportion of the copepods' diet, and that Acartia spp. often selectively consumed these ciliates over diatoms. However, Acartia spp. ingestion rates on all prey were consistently low and probably never high enough to enable substantial growth except during peak bloom conditions, which suggests that copepods may be food limited during non-bloom periods in the SFE (RollwagenBollens \& Penry 2003).

In the present study, the vertical distribution of Acartia spp. only showed significant correlation with that of non-Myrionecta aloricate ciliates during bloom periods, especially in 1998 when the chlorophyll bloom was exceptionally high. Perhaps the positive correlations between the vertical distributions of Acartia spp. and microplankton were due to high but non-saturating food conditions providing motivation for the copepods to aggregate at the same depth as their prey. In contrast, overall ciliate (and diatom) abundance may have been too low during the dry seasons for Acartia spp. to be induced to respond to the vertical distribution of their prey. Finally, 3 additional points are important:

First, as this was part of a larger program to investigate the role of heterotrophic protists in copepod diet, we only enumerated nanoplankton $>5 \mu \mathrm{m}$ in our samples (the lowest size efficiently grazed by Acartia spp.). Small heterotrophic nanoplankton (2 to $5 \mu \mathrm{m}$ ) might be highly abundant in coastal waters (e.g. Kuuppo 1994), and if we had included very small flagellates in our analyses we may have observed different, and possibly more significant, correlations between the WMD of microplankton predators and nanoplankton prey.

Second, we sampled the water column on a somewhat coarse scale, i.e. at $2 \mathrm{~m}$ increments. Although this depth spacing is comparable to that in the previous field studies discussed above, there is growing aware- 
ness that planktonic organisms can aggregate into even smaller, i.e. centimeter scale, 'thin layers.' Evidence for this comes from both field observations (e.g. Cowles \& Fessenden 1995, Montagnes et al. 1999, Dekshenieks et al. 2001, Alldredge et al. 2002, Rines et al. 2002) and experimental studies (Speekmann et al. 2000, Lougee et al. 2002, Bochdansky \& Bollens 2004, Clay et al. 2004, Ignoffo et al. 2005). It is possible that more highly vertically resolved sampling of micro- and nanoplankton in the SFE could reveal greater heterogeneity in vertical distributions than the results presented here based on $2 \mathrm{~m}$ depth increments.

Third, it was not within the scope of this study to directly measure other hydrographic parameters that may influence plankton distributions beyond stratification, such as tidal currents and freshwater flow, although we did record tidal stage at the beginning of each sampling cast (Table 1). A qualitative review of the tidal stage data in relation to the temporal variability in plankton weighted mean depths did not show any consistent patterns. It would be interesting to more explicitly measure how vertical distributions vary specifically on a tidal cycle. However, the fact that there were such dramatic diel differences in stratification, and at times tidal stage, but few if any differences in plankton vertical distributions, strengthens the argument that hydrography has little effect on plankton distributions in the SFE.

\section{SUMMARY AND CONCLUSIONS}

An important issue in marine ecology is whether it is possible to make reasonable predictions about the vertical distribution of plankton. Our data suggest that the vertical distribution of micro- and nanoplankton, in particular that of ciliates, is not directly related to the physical structure (i.e. the degree of stratification) of the SFE but instead is more influenced by biological interactions between potential predators and prey.

When overall microplankton abundance was low (i.e. San Pablo Bay, 1999, dry seasons) the vertical distribution of loricate ciliates, non-Myrionecta aloricate ciliates and dinoflagellates were all more strongly correlated with the distribution of their potential food (chlorophyll and autotrophic nanoflagellates) than that of their potential copepod predators (Acartia spp., Oithona davisae, Limnoithona tetraspina). This suggests that 'bottom-up' factors may be more important than 'top-down' factors in controlling microplankton vertical distribution in the SFE, at least during the dry season. However, when microplankton abundance was relatively high (i.e. South Bay, 1998, wet seasons), ciliate vertical distribution (especially that of aloricate forms) was more closely correlated to the distribution of their copepod predators (Acartia spp.), suggesting greater influence of 'top-down' factors.

In conclusion, distributions of micro- and nanoplankton in the SFE were often relatively homogeneous with depth and were surprisingly unrelated to water column hydrography. Vertical distributions of micro- and nanoplankton also showed limited variability on diel, seasonal and interannual time scales, as well as between 2 hydrodynamically very different locations within the SFE. However, on those occasions when temporal and/or spatial differences in planktonic vertical distributions did occur, correlation analyses led us to conclude that these patterns were more likely driven by biological pressures (predator-prey interactions) than by physical stratification of the water column.

Acknowledgements. The authors thank the marine operations staff at the Romberg Tiburon Center for Environmental Studies at San Francisco State University for field supprt aboard the RV 'Questuary'. We also thank 4 anonymous reviewers for their thoughful comments. This research was supported in large part by a National Science Foundation Alan T. Waterman award (OCE-9320572) to D.L.P.

\section{LITERATURE CITED}

Alldredge AL, Cowles TJ, MacIntyre S, Rines JEB and 6 others (2002) Occurrence and mechanism of formation of a dramatic thin layer of marine snow in a shallow Pacific fjord. Mar Ecol Prog Ser 233:1-12

Alpine AE, Cloern JE (1992) Trophic interactions and direct physical effects control phytoplankton biomass and production in an estuary. Limnol Oceanogr 37:946-955

Ambler JW, Cloern JE, Hutchinson A (1985) Seasonal cycles of zooplankton from San Francisco Bay. Hydrobiologia 129:177-197

Andersen CM, Nielsen TG (2002) The effect of a sharp pycnocline on plankton dynamics in a freshwater influenced Norwegian fjord. Ophelia 56:135-160

Armor C, Herrgesell PL (1985) Distribution and abundance of fishes in the San Francisco Bay estuary between 1980 and 1982. Hydrobiologia 129:211-227

Beet A, Solow AR, Bollens SM (2003) Comparing vertical plankton profiles with replication. Mar Ecol Prog Ser 262: 285-287

Bochdansky AB, Bollens SM (2004) Relevant scales in zooplankton ecology: distribution, feeding and reproduction of the copepod Acartia hudsonica in response to thin-layers of the diatom Skeletonema costatum. Limnol Oceanogr 49:625-636

Bojanic N, Solic M, Krstulovic N, Marasovic I, Nincevic Z, Vidjak O (2001) Seasonal and vertical distribution of the ciliated protozoa and micrometazoa in Kastela Bay (central Adriatic). Helgol Mar Res 55:150-159

Bollens SM, Frost BW (1989) Predator-induced diel vertical migration in a planktonic copepod. J Plankton Res 11: 1047-1065

Bollens SM, Frost BW (1991) Diel vertical migration in zooplankton: rapid individual response to predators. J Plankton Res 13:1359-1365

Bollens SM, Sanders A (2004) Ecology of larval Pacific herring Clupea pallasi in the San Francisco Estuary: seasonal and 
interannual abundance, distribution, diet and condition. Am Fish Soc Symp 36:15-35

Bollens SM, Osgood K, Frost B, Watts S (1993) Vertical distributions and susceptibilites to vertebrate predation of the marine copepods Metridia lucens and Calanus pacificus. Limnol Oceanogr 38:1827-1837

Bollens SM, Cordell JR, Avent S, Hooff R (2002) Zooplankton invasions: a brief review, plus two case studies from the Northeast Pacific Ocean. Hydrobiologia 480:87-110

Buskey EJ, Coulter C, Strom S (1993) Locomotory patterns of microzooplankton: potential effects on food selectivity of larval fish. Bull Mar Sci 53:29-43

Carrias JF, Amblard C, Bourdier G (1994) Vertical and temporal heterogeneity of planktonic ciliated protozoa in a humic lake. J Plankton Res 16:471-485

Clay TW, Bollens SM, Bochdansky AB, Ignoffo TR. (2004) The effects of thin layers on the vertical distribution of larval Pacific herring, Clupea pallasi. J Exp Mar Biol Ecol 305: 171-189

Cloern JE (1982) Does the benthos control phytoplankton biomass in South San Francisco Bay? Mar Ecol Progr Ser 9:191-202

Cloern JE (1987) Turbidity as a control on phytoplankton biomass and productivity in estuaries. Cont Shelf Res $7: 1367-1381$

Cloern JE (1991) Tidal sitrring and phytoplankton bloom dynamics in an estuary. J Mar Res 49:203-221

Cloern JE (1996) Phytoplankton bloom dynamics in coastal ecosystems: a review with some general lessons from sustained investigation of San Francisco Bay, California. Rev Geophys 34:127-168

Cloern JE, Dufford R (2005) Phytoplankton community ecology: principles applied in San Francisco Bay. Mar Ecol Prog Ser 285:11-28

Cloern JE, Cole BE, Wong RLJ, Alpine A (1985) Temporal dynamics of estuarine phytoplankton: a case study of San Francisco Bay. Hydrobiologia 129:153-176

Cole BE, Cloern JE, Alpine AE (1986) Biomass and productivity of three phytoplankton size classes in San Francisco Bay. Estuaries 9:117-126

Conomos TJ, Smith RE, Gartner JW (1985) Environmental setting of San Francisco Bay. Hydrobiologia 129:1-12

Cowles TJ, Fessenden LM (1995) Copepod grazing and finescale distribution patterns during the marine light-mixed layers experiment. J Geophys Res 100:6677-6686

Crawford DW, Lindholm T (1997) Some observations on vertical distribution and migration of the phototrophic ciliate Mesodinium rubrum (= Myrionecta rubra) in a stratified brackish inlet. Aquat Microb Ecol 13:267-274

Crawford DW, Purdie DA (1992) Evidence for avoidance of flushing from an estuary by a planktonic, phototrophic ciliate. Mar Ecol Prog Ser 79:259-265

Dale T (1987) Diel vertical distribution of planktonic ciliates in Landåspollene, western Norway. Mar Microb Food Webs $2: 15-28$

Dekshenieks MM, Donaghay PL, Sullivan JM, Rines JEB, Osborn TR, Twardowski MS (2001) Temporal and spatial occurrence of thin phytoplankton layers in relation to physical processes. Mar Ecol Prog Ser 223:61-71

Dolan JR (1991) Microphagous ciliates in mesohaline Chesapeake Bay waters - estimates of growth rates and consumption by copepods. Mar Biol 111:303-309

Dolan JR, Coats DW (1990) Seasonal abundances of planktonic ciliates and microflagellates in mesohaline Chesapeake Bay waters. Estuar Coast Shelf Sci 31:157-175

Dolan JR, Marrasé C (1995) Planktonic ciliate distribution relative to a deep chlorophyll maximum: Catalan Sea, NW
Mediterranean, June 1993. Deep-Sea Res 42:1965-1987

Fessenden L, Cowles TJ (1994) Copepod predation on phagotrophic ciliates in Oregon coastal waters. Mar Ecol Prog Ser 107:103-111

Figueroa FL, Niell FX, Figueiras FG, Villarino ML (1998) Diel migration of phytoplankton and spectral light field in the Ria de Vigo (NW Spain). Mar Biol 130:491-499

Gewant DS, Bollens SM (2005) Macrozooplankton and micronekton of the lower San Francisco Estuary: seasonal, interannual, and regional variation in relation to environmental conditions. Estuaries 28:473-485

Gifford DJ (1993) Consumption of protozoa by copepods feeding on natural microplankton assemblages. In: Kemp PF, Sherr BF, Sherr EB, Cole JJ (eds) Handbook of methods in aquatic microbial ecology. Lewis Publishers, Boca Raton, FL, p 723-729

Gifford DJ, Dagg MJ (1991) The microzooplankton-mesozooplankton link: consumption of planktonic protozoa by the calanoid copepods Acartia tonsa Dana and Neocalanus plumchrus Murukawa. Mar Microb Food Webs 5:161-177

Hansen PJ (1991) Quantitative importance and trophic role of heterotrophic dinoflagellates in a coastal pelagial food web. Mar Ecol Prog Ser 73:253-261

Hooff RC, Bollens SM (2004) Functional response and potential predatory impact of Tortanus dextrilobatus, a carnivorous copepod recently introduced to the San Francisco Estuary. Mar Ecol Prog Ser 277:167-179

Ignoffo TR, Bollens SM, Bochdansky AB (2005) The effects of thin layers on the vertical distribution of the rotifer, Brachionus plicatilis. J Exp Mar Biol Ecol 316:167-181

James MR, Hall JA (1995) Planktonic ciliated protozoa: their distribution and relationship to environmental variables in a marine coastal ecosystem. J Plankton Res 17:659-683

Jassby AD, Cloern JE, Cole BE (2002) Annual primary production: patterns and mechanisms of change in a nutrientrich tidal ecosystem. Limnol Oceanogr 47:698-712

Johnson MD, Stoecker DK (2005) Role of feeding and growth in photophysiology of Myrionecta rubra. Aquat Microb Ecol 39:303-312

Jonsson PR (1989) Vertical distribution of planktonic ciliates - an experimental analysis of swimming behaviour. Mar Ecol Prog Ser 52:39-53

Jonsson PR, Tiselius P (1990) Feeding behaviour, prey detection and capture efficiency of the copepod Acartia tonsa feeding on planktonic ciliates. Mar Ecol Prog Ser 60:35-44

Kimmerer WJ, Orsi JJ (1996) Changes in the zooplankton of the San Francisco Bay Estuary since the introduction of the clam Potamocorbula amurensis. In: Hollibaugh JT (ed) San Francisco Bay: the ecosystem. Pacific Division of American Association Advancement of Science, San Francisco, p 403-424

Kimmerer WJ, Burau JR, Bennett WA (1998) Tidally oriented vertical migration and position maintenance of zooplankton in a temperate estuary. Limnol Oceangr 43:1697-1709

Kleppel GS (1992) Environmental regulation of feeding and egg production by Acartia tonsa off southern California. Mar Biol 112:57-65

Kleppel GS, Burkart CA, Carter K, Tomas C (1996) Diets of calanoid copepods on the West Florida shelf: relationships between food concentration, food composition and feeding activity. Mar Biol 127:209-217

Kuuppo P (1994) Annual variation in the abundance and size of heterotrophic nanoflagellates on the SW coast of Finland, the Baltic Sea. J Plankton Res 16:1525-1542

Landry MR, Calbet A (2004) Microzooplankton production in the oceans. ICES J Mar Sci 61:501-507

Landry MR, Constantinou J, Kirshtein J (1995) Microzoo- 
plankton grazing in the central equatorial Pacific during February and August, 1992. Deep-Sea Res 42:657-671

Laprise R, Dodson JJ (1994) Environmental variability as a factor controlling spatial patterns in distribution and species diversity of zooplankton in the St. Lawrence Estuary. Mar Ecol Prog Ser 107:67-81

Lehman PW (2000) Phytoplankton biomass, cell diameter, and species composition in the low salinity zone of northern San Francisco Bay Estuary. Estuaries 23:216-230

Lessard EJ, Murrell MC (1998) Microzooplankton herbivory and phytoplankton growth in the northwestern Sargasso Sea. Aquat Microb Ecol 16:173-188

Lindholm T (1985) Mesodinium rubrum - a unique photosynthetic ciliate. Adv Aquat Microbiol 3:1-48

Lindholm T, Mork AC (1990) Depth maxima of Mesodinium rubrum (Lohmann) Hamburger \& Buddenbrock - examples from a stratified Baltic Sea inlet. Sarsia 75:53-64

Lougee LA, Bollens SM, Avent SR (2002) The effects of haloclines on the vertical distribution and migration of zooplankton. J Exp Mar Biol Ecol 278:111-134

Meng L, Moyle PB, Herbold B (1994) Changes in abundance and distribution of native and introduced fishes of Suisun Marsh. Trans Am Fish Soc 123:498-507

Montagnes DJS, Poulton AJ, Shammon TM (1999) Mesoscale, finescale and microscale distribution of micro- and nanoplankton in the Irish Sea, with emphasis on ciliates and their prey. Mar Biol 134:167-179

Nejstgaard JC, Gismervik I, Solberg PT (1997) Feeding and reproduction by Calanus finmarchicus, and microzooplankton grazing during mesocosm blooms of diatoms and the coccolithophore Emiliania huxleyi. Mar Ecol Prog Ser 147:197-217

Nejstgaard JC, Naustvoll LJ, Sazhin A (2001) Correcting for underestimation of microzooplankton grazing in bottle incubation experiments with mesozooplankton. Mar Ecol Prog Ser 221:59-75

Nichols FH (1985) Increased benthic grazing: an alternative explanation for low phytoplankton biomass in northern San Francisco Bay during the 1976-77 drought. Estuar Coast Shelf Sci 21:379-388

Nichols FH, Thompson JK, Schemel LE (1990) Remarkable invasion of San Francisco Bay (California, USA) by the Asian clam Potamocorbula amurensis. 2. Displacement of a former community. Mar Ecol Prog Ser 66:95-101

Nival P, Nival S (1976) Particle retention efficiencies of an herbivorous copepod, Acartia clausi (adult and copepodite stages): effects on grazing. Limnol Oceanogr 21:24-38

Olli K, Heiskanen AS, Lohikari K (1998) Vertical migration of autotrophic micro-organisms during a vernal bloom at the coastal Baltic Sea - coexistence through niche separation. Hydrobiologia 363:179-189

Pace ML (1982) Planktonic ciliates: their distribution, abundance, and relationship to microbial resources in a monomictic lake. Can J Fish Aquat Sci 39:1106-1116

Passow U (1991) Vertical migration of Gonyaulax catenata and Mesodinium rubrum. Mar Biol 110:455-463

Perez MT, Dolan JR, Vidussi R, Fukai E (2000) Diel vertical distribution of planktonic ciliates within the surface layer of the NW Mediterranean (May 1995). Deep-Sea Res 47: 479-503

Pierce RW, Turner JT (1992) Ecology of planktonic ciliates in marine food webs. Rev Aquat Sci 6:139-181

Pitta P, Giannakourou A (2000) Planktonic ciliates in the oligotrophic eastern Meditarranean: vertical, spatial distribution and mixotrophy. Mar Ecol Prog Ser 194:269-282

Porter KG, Sherr EB, Sherr BF, Pace M, Sanders RW (1985) Protozoa in planktonic food webs. J Protozool 32:409-415
Purkerson DG, Doblin MA, Bollens SM, Luoma SN, Cutter GA (2003) Selenium in San Francisco Bay zooplankton: potential effects of hydrodynamics and food web interactions. Estuaries 26:956-969

Revelante N, Gilmartin M (1990) Vertical water column resource partitioning by a ciliated protozoan population under stratified conditions in the northern Adriatic. J Plankton Res 12:89-107

Rines JEB, Donaghay PL, Dekshenieks MM, Sullivan JM, Twardowski MS (2002) Thin layers and camouflage: hidden Pseudo-nitzschia spp. (Bacillariophyceae) populations in a fjord in the San Juan Islands, Washington, USA. Mar Ecol Prog Ser 225:123-137

Rollwagen-Bollens GC, Penry DL (2003) Feeding dynamics of Acartia spp. copepods in a large, temperate estuary (San Francisco Bay, CA). Mar Ecol Prog Ser 257:139-158

Sanders RW (1987) Tintinnids and other microzooplankton seasonal distributions and relationships to resources and hydrography in a marine estuary. J Plankton Res 9:65-77

Sherr EB, Sherr BF (1987) High rates of consumption of bacteria by pelagic ciliates. Nature 325:710-711

Sherr EB, Sherr BF (1994) Bacterivory and herbivory: key roles of phagotrophic protists in pelagic food webs. Microb Ecol 28:223-235

Sherr EB, Caron DA, Sherr BF (1993) Staining of heterotrophic protists for visualization via epifluorescence microscopy. In: Kemp PF, Sherr BF, Sherr EB, Cole JJ (eds) Handbook of methods in aquatic microbial ecology. Lewis Publishers, Boca Raton, FL, p $213-227$

Sieburth JM, Smetacek V, Lenz J (1978) Pelagic ecosystem structure: heterotrophic compartments of the plankton and their relationship to plankton size fractions. Limnol Oceanogr 23:1256-1263

Smith RE, Herndon RE, Harmo DD (1979) Physical and chemical properties of San Francisco Bay waters, 1969-1976. US Geological Survey Open File Report 79511

Solow AR, Beet A, Bollens SM (2000) Comparing two vertical distributions. Limnol Oceanogr 45:506-509

Speekmann CL, Bollens SM, Avent SR (2000) The effect of ultraviolet radiation on the vertical distribution and mortality of estuarine zooplankton. J Plankton Res 22: $2325-2350$

Stearns DE, Forward RBJ (1984) Copepod photobehavior in a simulated natural light environment. Mar Biol 82:91-100

Stevens DE (1977) Striped bass (Morone saxatilis) year class strength in relation to river flow in the Sacramento-San Joaquin estuary, California. Trans Am Fish Soc 114:34-42

Stoecker DK, Davis LH, Anderson DM (1984) Fine scale spatial correlations between planktonic ciliates and dinoflagellates. J Plankton Res 6:829-842

Strickland JDH, Parsons TR (1972) A practical manual for seawater analysis, 2nd edn. Bull Fish Res Board Can $167: 1-310$

Strom SL (2000) Bacterivory: interactions between bacteria and their grazers. In: Kirchman DL (ed) Microbial ecology of the oceans. Wiley-Liss, New York, p 351-386

Suzuki K, Taniguchi A (1998) Standing crops and vertical distribution of four groups of marine planktonic ciliates in relation to phytoplankton chlorophyll a. Mar Biol 132: 375-382

Suzuki K, Tsuda A, Kiyosawa H, Takeda S, Nishioka J, Saino T, Takahashi M, Wong CS (2002) Grazing impact of microzooplankton on a diatom bloom in a mesocosm as estimated by pigment-specific dilution technique. J Exp Mar Biol Ecol 271:99-120

Tamigneaux E, Mingelbier M, Klein B, Legendre L (1997) 
Grazing by protists and seasonal changes in the size structure of the protozooplankton and phytoplankton in a temperate nearshore environment (western Gulf of St. Lawrence, Canada). Mar Ecol Prog Ser 146:231-247

Thompson B, Hoenicke R, Davis JA, Gunther A and 5 others (2000) An overview of contaminant-related issues identified by monitoring in San Francisco Bay. Environ Monit Assess 64:409-419

Throndsen J (1978) Preservation and storage. In: Sournia A (ed) Phytoplankton manual. UNESCO, Paris, p 69-74

Titelman J, Tiselius P (1998) Vertical distribution, grazing and egg production of calanoid copepods during winterspring in Gullmarsfjorden. Hydrobiologia 375/376: 343-351

Uchima M, Hirano R (1988) Swimming behavior of the marine copepod Oithona davisae: internal control and search for environment. Mar Biol 99:47-56

Vacqué D, Pace ML, Findlay S, Lints D (1992) Fate of bacterial production in a heterotrophic ecosystem: grazing by

Editorial responsibility: Urania Christaki,

Wimereux, France protists and metazoans in the Hudson Estuary. Mar Ecol Prog Ser 89:155-163

Verity PG (1987) Abundance, community composition, size distribution, and production rates of tintinnids in Narragansett Bay, Rhode Island. Estuar Coast Shelf Sci 24:671-690

Verity PG, Paffenhöfer GA (1996) On assessment of prey ingestion by copepods. J Plankton Res 18:1767-1779

Villarino ML, Figueiras FG, Jones KJ, Alvarez-Salgado XA, Richard J, Edwards A (1995) Evidence of in situ diel vertical migration of a red-tide microplankton species in Ria de Vigo (NW Spain). Mar Biol 123:607-617

Zar JH (1996) Biostatistical analysis, 3rd edn. Prentice Hall, Upper Saddle River, NJ

Zeldis J, James MR, Grieve J, Richards L (2002) Omnivory by copepods in the New Zealand subtropical frontal zone. J Plankton Res 24:9-23

Zingel R, Ott I (2000) Vertical distribution of planktonic ciliates in strongly stratified temperate lakes. Hydrobiologia 435:19-26

Submitted: January 10, 2006; Accepted: April 14, 2006

Proofs received from author(s): September 4, 2006 